\title{
Photoluminescence of Pentavalent Uranyl Amide Complexes
}

DOI:

10.1021/jacs.1c05184

\section{Document Version}

Final published version

Link to publication record in Manchester Research Explorer

\section{Citation for published version (APA):}

Natrajan, L., Woodward, A., Ortu, F., Moulding, D., Randall, S., Kerridge, A., Meyer, K., \& Storms La Pierre, H. (2021). Photoluminescence of Pentavalent Uranyl Amide Complexes. Journal of the American Chemical Society/J Am Chem Soc. https://doi.org/10.1021/jacs.1c05184

\section{Published in:}

Journal of the American Chemical Society|J Am Chem Soc

\section{Citing this paper}

Please note that where the full-text provided on Manchester Research Explorer is the Author Accepted Manuscript or Proof version this may differ from the final Published version. If citing, it is advised that you check and use the publisher's definitive version.

\section{General rights}

Copyright and moral rights for the publications made accessible in the Research Explorer are retained by the authors and/or other copyright owners and it is a condition of accessing publications that users recognise and abide by the legal requirements associated with these rights.

\section{Takedown policy}

If you believe that this document breaches copyright please refer to the University of Manchester's Takedown Procedures [http://man.ac.uk/04Y6Bo] or contact uml.scholarlycommunications@manchester.ac.uk providing relevant details, so we can investigate your claim.

\section{OPEN ACCESS}




\title{
Photoluminescence of Pentavalent Uranyl Amide Complexes
}

\author{
Fabrizio Ortu, ${ }^{\nabla}$ Simon Randall, ${ }^{\nabla}$ David J. Moulding, Adam W. Woodward, Andrew Kerridge, \\ Karsten Meyer, Henry S. La Pierre,* and Louise S. Natrajan*
}

Cite This: J. Am. Chem. Soc. 2021, 143, 13184-13194

Read Online

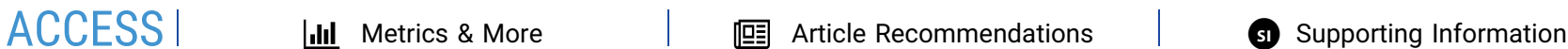

ABSTRACT: Pentavalent uranyl species are crucial intermediates in transformations that play a key role for the nuclear industry and have recently been demonstrated to persist in reducing biotic and abiotic aqueous environments. However, due to the inherent instability of pentavalent uranyl, little is known about its electronic structure. Herein, we report the synthesis and characterization of a series of monomeric and dimeric, pentavalent uranyl amide complexes. These synthetic efforts enable the acquisition of emission spectra of welldefined pentavalent uranyl complexes using photoluminescence techniques, which establish a unique signature to characterize its electronic structure and, potentially, its role in biological and engineered environments via emission spectroscopy.

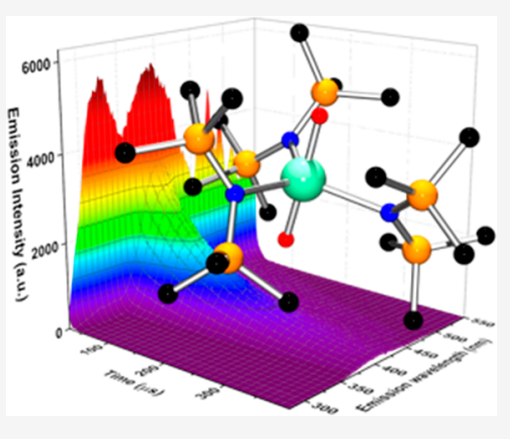

\section{INTRODUCTION}

The aqueous chemistry of uranium is dominated by the uranyl dication, $\left[\mathrm{U}^{\mathrm{VI}} \mathrm{O}_{2}\right]^{2+1-4}$ Therefore, understanding its physicochemical properties is vital to the successful implementation of adequate nuclear waste management strategies. ${ }^{5-9}$ Despite its inherent stability, uranyl can undergo a number of transformations in the environment, the cornerstone of which is the reduction of soluble uranyl(VI) to insoluble $\mathrm{U}^{4+} .{ }^{10}$ This transformation has been postulated to proceed via a disproportionation mechanism, which involves the formation of transient uranyl $(\mathrm{V})$ species, $\left\{\left[\mathrm{U}^{\mathrm{V}} \mathrm{O}_{2}\right]^{+}\right\}_{n}(n=1$ or 2$){ }^{11,12}$ The detection of this transient species in the environment and in biological systems remains a challenging goal due to its redox instability and lability. ${ }^{13}$

In aqueous media, $\left[\mathrm{U}^{\mathrm{V}} \mathrm{O}_{2}\right]^{+}$has been observed in acidic solutions $(\mathrm{pH} 2-3)^{14}$ and in concentrated carbonate solutions. ${ }^{15}$ Molecular $\left[\mathrm{U}^{\mathrm{V}} \mathrm{O}_{2}\right]^{+}$compounds have also been stabilized by operating in the rigorous exclusion of air and moisture., 96,17 Quite remarkably, they have recently been isolated and studied in aqueous media. ${ }^{18-20}$ Since 2003, ${ }^{21}$ there have been a number of reports on the structural and chemical properties of the once elusive $\left[\mathrm{U}^{\mathrm{V}} \mathrm{O}_{2}\right]^{+}$cation. ${ }^{9,16,17,22-29}$ Nevertheless, there is a remarkable paucity of information regarding the electronic structure and photophysical properties of $\left[\mathrm{U}^{\mathrm{V}} \mathrm{O}_{2}\right]^{+} \cdot{ }^{30}$ This is in contrast to the extensive studies of the $\left[\mathrm{U}^{\mathrm{VI}} \mathrm{O}_{2}\right]^{2+}$ dication. In prior seminal reports on the emission spectra of $\left[\mathrm{U}^{\mathrm{V}} \mathrm{O}_{2}\right]^{+}$species, ${ }^{31,32}$ $\left[\mathrm{U}^{\mathrm{V}} \mathrm{O}_{2}\right]^{+}$was generated in situ using photolytic or electrolytic reduction and analysis required deconvolution of the luminescence spectra. Very recently, Mazzanti and co-workers reported the emission spectra of a water-stable dipicolinate $\left[\mathrm{U}^{\mathrm{V}} \mathrm{O}_{2}\right]^{+}$complex. ${ }^{20}$ However, the photophysical properties of the $\left[\mathrm{U}^{\mathrm{V}} \mathrm{O}_{2}\right]^{+}$cation remain unassigned. We have previously shown that the application of photoluminescence techniques to $\left[\mathrm{U}^{\mathrm{VI}} \mathrm{O}_{2}\right]^{2+}$ can provide detailed information regarding the behavior of uranyl, particularly its coordination, speciation, and nuclearity including the existence of "cation-cation" interactions (CCIs). ${ }^{33}$ Therefore, the application of this approach to discrete molecular $\left[\mathrm{U}^{\mathrm{V}} \mathrm{O}_{2}\right]^{+}$compounds can offer a essential diagnostic tools for understanding its physicochemical properties. ${ }^{13}$ Herein, we report the synthesis and structural authentication of a series of pentavalent uranyl complexes and the detailed characterization of their photoluminescence properties.

\section{EXPERIMENTAL SECTION}

General Methods. Caution! ${ }^{238} U\left(t_{1 / 2}=4.47 \times 10^{9}\right.$ years $)$ is a weak $\alpha$-emitter; therefore, all manipulations should be performed in suitable laboratories that have been designated for radiochemical use, and $\alpha$-counting equipment should be available. All manipulations were carried out using standard Schlenk techniques or in an Inert Purelab HE 2GB glovebox. Solvents were dried by refluxing over potassium and were distilled and degassed before use. All solvents were stored over potassium mirrors (with the exception of THF and DME, which were stored over activated $4 \AA$ molecular sieves $)$. [K(THF $\left.)_{3}\right]$ $\left[\mathrm{UO}_{2}\left(\mathrm{~N}^{\prime \prime}\right)_{3}\right](\mathbf{1}),[\mathrm{K}(\mathrm{crypt})]\left[\mathrm{UO}_{2}\left(\mathrm{~N}^{\prime \prime}\right)_{3}\right]$ (2-crypt), $\left[\mathrm{UO}_{2}\left(\mathrm{~N}^{\prime \prime}\right)_{2}(\mathrm{THF})_{2}\right]$ (4) were prepared following literature procedures. ${ }^{34} \mathrm{H},{ }^{13} \mathrm{C}\left\{{ }^{1} \mathrm{H}\right\}$, and ${ }^{29} \mathrm{Si}\left\{{ }^{1} \mathrm{H}\right\}$ NMR spectra were recorded at $298 \mathrm{~K}$ on a Bruker Avance 400 spectrometer operating at 400.2, 100.6, and 79.5 MHz, respectively; chemical shifts are quoted in ppm

Received: May 19, 2021

Published: August 13, 2021 
and are relative to TMS. FTIR spectra were recorded as Nujol mulls in $\mathrm{KBr}$ discs using a Shimadzu IRAffinity-1S spectrometer. Raman spectra were recorded using a XploRAPLUS Horiba Scientific spectrometer. Electronic absorption spectra were recorded in sealed $10 \mathrm{~mm}$ path length cuvettes using a Shimadzu UV-2600 spectrometer.

Synthesis. [K(18-crown-6)][UO $\left.{ }_{2}\left(N^{\prime \prime}\right)_{3}\right](2-18 C 6)$. A Schlenk flask fitted with magnetic stir bar was charged with $4(1.225 \mathrm{~g}, 1.7 \mathrm{mmol})$, $\mathrm{KN}^{\prime \prime}(0.356 \mathrm{~g}, 1.8 \mathrm{mmol})$ and 18 -crown-6 (0.467 g, $\left.1.8 \mathrm{mmol}\right)$; the flask was cooled to $-50{ }^{\circ} \mathrm{C}$, THF $(15 \mathrm{~mL})$ was added and the orange solution stirred for $16 \mathrm{~h}$ at room temperature. Volatiles were removed under reduced pressure and the solid washed with hexane $(10 \mathrm{~mL})$, then dried in vacuo for $2 \mathrm{~h}$ at room temperature, affording $2-18 \mathrm{C} 6$ as an orange powder. Yield: $1.416 \mathrm{~g}, 1.3 \mathrm{mmol}, 80 \%$. Anal. Calc'd (\%) for $\mathrm{C}_{30} \mathrm{H}_{78} \mathrm{KN}_{3} \mathrm{O}_{8} \mathrm{Si}_{6} \mathrm{U}$ : C 34.17, $\mathrm{H}$ 7.45, N 3.98; Found: C 34.14, $\mathrm{H}$ 7.44, N 3.61. ${ }^{1} \mathrm{H}$ NMR (pyridine- $\left.d_{6}, 298 \mathrm{~K}, 400 \mathrm{MHz}\right) \delta 0.79(\mathrm{~s}, 36 \mathrm{H}$, $\left.\mathrm{Si}\left(\mathrm{CH}_{3}\right)_{3}\right), 3.50$ (s, 24H, 18-crown-6- $\left.\mathrm{CH}_{2}\right) .{ }^{13} \mathrm{C}\left\{{ }^{1} \mathrm{H}\right\}$ NMR (pyridine- $\left.d_{6}, 298 \mathrm{~K}, 100 \mathrm{MHz}\right) \delta 6.86\left(\mathrm{Si}\left(\mathrm{CH}_{3}\right)_{3}\right), 70.95(18-$ crown-6- $\mathrm{CH}_{2}$ ). ${ }^{29} \mathrm{Si}\left\{{ }^{1} \mathrm{H}\right\}$ (pyridine- $\left.d_{6}, 298 \mathrm{~K}, 79.5 \mathrm{MHz}\right) \delta-8.52$ $\left(\mathrm{Si}\left(\mathrm{CH}_{3}\right)_{3}\right)$. FTIR (ATR microcrystalline) $\tilde{\nu} 2945(\mathrm{w}), 2892(\mathrm{w})$, $1352(\mathrm{w}), 1233(\mathrm{~m}), 1103$ (s), 959 (vs, $\mathrm{U}=\mathrm{O}_{\text {asym }}$ ), 833 (vs), 770 $(\mathrm{w}), 689(\mathrm{w}), 658(\mathrm{~s}), 607(\mathrm{~s}) \mathrm{cm}^{-1}$. FTIR (ATR) $\tilde{\nu} 2971(\mathrm{br}, \mathrm{m})$, 2859 (br, m), 1454 (w), 1352 (w), 1233 (w), 1107 (m), 1066 (vs), $961\left(\mathrm{~s}, \mathrm{U}=\mathrm{O}_{\text {asym }}\right), 907(\mathrm{w}), 834(\mathrm{vs}), 768(\mathrm{w}), 668(\mathrm{w}), 661(\mathrm{~m})$, 605 (m). Raman (Solid, 638 nm, 100\%) $\tilde{\nu} 2904$ (br, 799), 1474 (640), 1278 (600), 1247 (479), 1135 (492), 802 (2257) $\left(\mathrm{U}=\mathrm{O}_{\text {sym }}\right)$, $280(1256) \mathrm{cm}^{-1}$ (counts). UV/vis $\left(0.05 \mathrm{mM}\right.$, THF) $\lambda_{\max }\left(\varepsilon / \mathrm{mol}^{-1}\right.$ $\mathrm{cm}^{-1}$ ): 497 (270), 370 (2632), 324 (4018), 230 (5262), 212 (5026) nm. 2-18C6-THF: Crystals were grown form a THF solution layered with hexane and stored at $-25^{\circ} \mathrm{C}$ several days. 2-18C6-Tol: Crystals were grown from cooling of a boiling toluene solution. 2-18C6$\mathrm{CHCl}_{3}$ : Crystals were grown from a saturated solution in $\mathrm{CHCl}_{3}$ at room temperature.

$\left[K\left(2.2 .2\right.\right.$-cryptand)][UO $\left.{ }_{2}{ }^{\prime \prime}{ }_{3}\right]$ (2-crypt). A Schlenk flask fitted with magnetic stir bar was charged with $1(1.701 \mathrm{~g}, 1.7 \mathrm{mmol})$ and 2.2.2cryptand $(0.636 \mathrm{~g}, 1.7 \mathrm{mmol})$; DME $(20 \mathrm{~mL})$ was added and the reaction stirred for $4 \mathrm{~h}$. The deep red solution was concentrated to 5 $\mathrm{mL}$ and stored at $-30{ }^{\circ} \mathrm{C}$, affording 2-crypt as bright red crystals (1.595 g, $1.4 \mathrm{mmol}, 80 \%)$. Spectroscopic data matched that previously reported in the literature. ${ }^{34}$

$[K(18-c r o w n-6)(D M E)]_{2}\left[\cup O_{2}\left(N^{\prime \prime}\right)_{3}\right](3-18 C 6)$. A Schlenk flask with a stirrer bar was charged with 2-18C6 $(0.836 \mathrm{~g}, 0.79 \mathrm{mmol})$. Additionally, a separate flask was charged with a mixture of 18-crown$6(0.220 \mathrm{~g}, 0.83 \mathrm{mmol})$ and $\mathrm{KC}_{8}(0.109 \mathrm{~g}, 0.80 \mathrm{mmol})$. Both flasks were cooled to $-50{ }^{\circ} \mathrm{C}$ and DME (5 mL each) was added. Both mixtures were stirred for $5 \mathrm{~min}$, then the slurry of 18-crown-6 and $\mathrm{KC}_{8}$ was added quickly to the solution of 1-18C6. More DME (2 $\mathrm{mL}$ ) was added in order to collect the rest of the $\mathrm{KC}_{8}$ slurry and complete the addition. The reaction was allowed to stir at $-50{ }^{\circ} \mathrm{C}$ for $5 \mathrm{~min}$ and then left to settle for $2 \mathrm{~min}$. The suspension was then filtered into a precooled Schlenk flask $\left(-50^{\circ} \mathrm{C}\right)$ affording an emerald green solution. Subsequent concentration of the mother liqueur at $-30{ }^{\circ} \mathrm{C}$ (ca. $\left.5 \mathrm{~mL}\right)$ followed by layering with pentane $(7 \mathrm{~mL})$ and storage at $-30{ }^{\circ} \mathrm{C}$ led to emerald green crystals of 3-18C6. Yield: $0.344 \mathrm{~g}, 0.21 \mathrm{mmol}, 27 \% .{ }^{1} \mathrm{H}$ NMR (tetrahydrofuran- $d_{8}, 298 \mathrm{~K}$ ) $\delta$ $-8.64\left(\mathrm{br}, \nu 1 / 2=52 \mathrm{~Hz}, 18 \mathrm{H}, \mathrm{Si}\left(\mathrm{CH}_{3}\right)_{3}\right),-4.94(\mathrm{br}, \nu 1 / 2=340 \mathrm{~Hz}$, $\left.9 \mathrm{H}, \mathrm{Si}\left(\mathrm{CH}_{3}\right)_{3}\right), 3.28(\mathrm{~s}, \nu 1 / 2=3 \mathrm{~Hz}, 12 \mathrm{H}, \mathrm{DME}), 3.44(\mathrm{~s}, \nu 1 / 2=4$ $\mathrm{Hz}, 8 \mathrm{H}, \mathrm{DME}), 6.44\left(\mathrm{br}, \nu 1 / 2=44 \mathrm{~Hz}, 24 \mathrm{H}\right.$, crown $\left.-\mathrm{CH}_{2}\right) \cdot{ }^{13} \mathrm{C}\left\{{ }^{1} \mathrm{H}\right\}$ NMR (tetrahydrofuran- $\left.d_{8}, 298 \mathrm{~K}\right) \delta 6.29\left(\mathrm{~s}, \mathrm{Si}\left(\mathrm{CH}_{3}\right)_{3}\right), 6.50(\mathrm{~s}$, $\left.\mathrm{Si}\left(\mathrm{CH}_{3}\right)_{3}\right), 58.95$ (s, DME), 72.83 (s, DME), 73.35 (br, 18-crown-6$\left.\mathrm{CH}_{2}\right) .{ }^{29} \mathrm{Si}\left\{{ }^{1} \mathrm{H}\right\}$ NMR $\left(d_{8}\right.$-THF, $\left.298 \mathrm{~K}\right) \delta-10.87\left(\mathrm{Si}\left(\mathrm{CH}_{3}\right)_{3}\right) . \mu_{\text {eff }}$ (Evans method, $298 \mathrm{~K}$, tetrahydrofuran- $d_{8}$ ) $2.68 \mu_{\mathrm{B}}$. FTIR (ATR microcrystalline) $\tilde{\nu} 2889(\mathrm{br}, \mathrm{m}), 1452(\mathrm{w}), 1352(\mathrm{~m}), 1233(\mathrm{~m})$, 1103 (vs), 1025 (s), 958 (s), 873 (m, $\mathrm{U}=\mathrm{O}_{(\mathrm{yl}) \text { asym }}$ ), 821 (vs), 758 (s), $695(\mathrm{w}), 650(\mathrm{~s}), 591(\mathrm{w}) \mathrm{cm}^{-1}$. Raman (solid, $\left.638 \mathrm{~nm}, 10 \%\right)$ (Smoothed) $\tilde{\nu} 2893$ (br, s), 1475 (w), $1282(\mathrm{w}), 1142(\mathrm{w}), 837$ (m), 727 (br, s, $\mathrm{U}=\mathrm{O}_{(\mathrm{yl}) \text { sym }}$ ), 609 (w), 415 (br, m), 282 (br, w). Anal. Calc'd (\%) for $\mathrm{C}_{46} \mathrm{H}_{112} \mathrm{~K}_{2} \mathrm{~N}_{3} \mathrm{O}_{16} \mathrm{Si}_{6} \mathrm{U} \cdot \mathrm{C}_{4} \mathrm{H}_{10} \mathrm{O}_{2}$ : C 38.15, $\mathrm{H}$ 7.80, N 2.90; Found: C 37.92, H 7.83, N 2.57. UV/vis (2.65 mM, THF) $\lambda_{\max }$ $\left(\varepsilon / \mathrm{mol}^{-1} \mathrm{~cm}^{-1}\right): 773$ (45), 650 (60), 622-shoulder (58), 567shoulder (71) 496 (150) $\mathrm{nm}$.
$[K(2.2 .2 \text {-cryptand })]_{2}\left[\cup_{2}\left(N^{\prime \prime}\right)_{3}\right]$ (3-crypt). A Schlenk flask fitted with a stirrer bar was charged with 2-crypt $(1.084 \mathrm{~g}, 0.9 \mathrm{mmol})$; a separate flask was charged with a mixture of 2.2.2-cryptand $(0.350 \mathrm{~g}$, $0.9 \mathrm{mmol})$ and $\mathrm{KC}_{8}(0.126 \mathrm{~g}, 0.9 \mathrm{mmol})$. Both flasks were cooled to $-50{ }^{\circ} \mathrm{C}$ and DME ( 5 and $10 \mathrm{~mL}$ respectively) was added. The slurry of 2.2.2-cryptand and $\mathrm{KC}_{8}$ was added quickly to the solution of 2crypt; more DME $(5 \mathrm{~mL})$ was added in order to collect the rest of the $\mathrm{KC}_{8}$ slurry and complete the addition. The reaction was allowed to stir at $-50{ }^{\circ} \mathrm{C}$ and then filtered in a precooled Schlenk flask (-50 ${ }^{\circ} \mathrm{C}$ ), affording a bright green solution. The solution was stored at -25 ${ }^{\circ} \mathrm{C}$, affording 3-crypt as emerald green crystals $(0.791 \mathrm{~g}, 0.5 \mathrm{mmol}$, $51 \%) .{ }^{1} \mathrm{H}$ NMR (tetrahydrofuran- $\left.d_{8}, 298 \mathrm{~K}, 400 \mathrm{MHz}\right) \delta-8.47(\mathrm{br}$, $\left.\nu_{1 / 2}=60 \mathrm{~Hz}, 5 \mathrm{H}, \mathrm{N}\left(\mathrm{SiCH}_{3}\right)_{2}\right),-4.75\left(\mathrm{br}, \nu_{1 / 2}=324 \mathrm{~Hz}, 36 \mathrm{H}\right.$, $\left.\mathrm{N}\left(\mathrm{SiCH}_{3}\right)_{2}\right),-0.09\left(\mathrm{~s}, \nu_{1 / 2}=4 \mathrm{~Hz}, 9 \mathrm{H}, \mathrm{N}\left(\mathrm{SiCH}_{3}\right)_{2}\right), 0.33\left(\mathrm{~s}, \nu_{1 / 2}=4\right.$ $\left.\mathrm{Hz}, 4 \mathrm{H}, \mathrm{N}\left(\mathrm{SiCH}_{3}\right)_{2}\right), 6.72\left(\mathrm{br}, \nu_{1 / 2}=24 \mathrm{~Hz}, 24 \mathrm{H}\right.$, crypt $\left.-\mathrm{CH}_{2}\right), 8.17$ (br, $\nu_{1 / 2}=36 \mathrm{~Hz}, 24 \mathrm{H}$, crypt $\left.-\mathrm{CH}_{2}\right), 8.71\left(\mathrm{br}, \nu_{1 / 2}=40 \mathrm{~Hz}, 24 \mathrm{H}\right.$, crypt-C $\mathrm{CH}_{2}$ ) ppm. ${ }^{13} \mathrm{C}\left\{{ }^{1} \mathrm{H}\right\}$ NMR (tetrahydrofuran- $d_{8}, 298 \mathrm{~K}, 100$ $\mathrm{MHz}) \delta 6.39\left(\mathrm{~N}\left(\mathrm{SiCH}_{3}\right)_{2}\right), 7.09\left(\mathrm{~N}\left(\mathrm{SiCH}_{3}\right)_{2}\right), 58.66\left(\right.$ crypt- $\left.\mathrm{CH}_{2}\right)$, $72.64\left(\right.$ crypt- $\left.\mathrm{CH}_{2}\right), 75.90\left(\right.$ crypt- $\left.\mathrm{CH}_{2}\right)$ ppm. ${ }^{29} \mathrm{Si}\left\{{ }^{1} \mathrm{H}\right\}$ (tetrahydrofuran- $\left.d_{8}, 298 \mathrm{~K}, 79.5 \mathrm{MHz}\right) \delta-103.12 \mathrm{ppm}$. $\mu_{\text {eff }}$ (Evans method, $298 \mathrm{~K}$, tetrahydrofuran- $\left.d_{8}\right) \quad 2.47 \mu_{\mathrm{B}}$. Anal. Calcd (\%) for $\mathrm{C}_{54} \mathrm{H}_{126} \mathrm{~K}_{2} \mathrm{~N}_{7} \mathrm{O}_{14} \mathrm{Si}_{6} \mathrm{U}$ : C 40.99, H 8.03, N 6.20; found: C 40.92, $\mathrm{H}$ 8.31, N 6.09. UV/vis (3.1 mM, DME) $\lambda_{\max }\left(\varepsilon / \mathrm{mol}^{-1} \mathrm{~cm}^{-1}\right): 649$ (136), 622 (57), 490 (37) nm. FTIR (KBr disc in Nujol mull) $\tilde{\nu} 1722$ $(\mathrm{w}), 1622(\mathrm{w}), 1362(\mathrm{~s}), 1296(\mathrm{~s}), 1261(\mathrm{~m}), 1236(\mathrm{~m}), 1223(\mathrm{~m})$, 1175 (w), 1101 (br s w/shoulder), 1030 (br s), $949(\mathrm{~m}), 932(\mathrm{w})$, $872\left(\mathrm{~m}, \mathrm{U}=\mathrm{O}_{\text {asym }}\right), 816$ (br s), 762 (m w/shoulder), $698(\mathrm{w}), 662$ (m), $648(\mathrm{~m}), 582-360(\mathrm{br} \mathrm{s}) \mathrm{cm}^{-1}$. Raman (50 mM in THF) $\tilde{\nu}$ 753(544), 829(705) $\mathrm{cm}^{-1}$ (counts), $\left(\mathrm{U}=\mathrm{O}_{(\mathrm{yl}) \text { sym }}\right)$; Raman (solid, $532 \mathrm{~nm}, 100 \%) \tilde{\nu}$ 164(127), 192(158), 488(636), 709(279), 790(126), 1416(74) $\mathrm{cm}^{-1}$ (counts).

$[K(18-c r o w n-6)(D M E)]_{2}\left[\left\{U O(\mu-O)\left(N^{\prime \prime}\right)_{2}\right\}_{2}\right]$ (5) and $[K(18$-crown6) $(D M E)]_{2}\left[\left\{U O_{2}\left(\mu-O_{2}\right)\left(N^{\prime \prime}\right)_{2}\right\}_{2}\right]$ (6). In the glovebox, to a vial containing a magnetic stirrer bar was added $4(250 \mathrm{mg}, 0.34 \mathrm{mmol})$ and $10 \mathrm{~mL}$ of 1:1 THF:hexane. The mixture was stirred and the dark orange solution transferred to a $-35{ }^{\circ} \mathrm{C}$ freezer. $\mathrm{KC}_{8}(46 \mathrm{mg}, 0.34 \mathrm{mmol})$ and 2.2.2-cryptand $(0.128 \mathrm{mg}, 0.34 \mathrm{mmol})$ were weighed into separate vials, the crypt dissolved in $4 \mathrm{~mL}$ of THF and the vials stored at -35 ${ }^{\circ} \mathrm{C}$. After $30 \mathrm{~min}$, the THF/cryptand solution was transferred to the $\mathrm{KC}_{8}$ and the resulting slurry added to the uranyl solution dropwise over 2 min with vigorous stirring. Washings were transferred with an additional $2 \mathrm{~mL}$ of cold THF and the mixture stirred for a further minute before being moved to the $-35{ }^{\circ} \mathrm{C}$ freezer for $1 \mathrm{~min}$. The slurry was stirred and filtered through a fine porosity frit and the brown filtrate concentrated to ca. $3 \mathrm{~mL}$ under reduced pressure and cooled to $-35{ }^{\circ} \mathrm{C}$. The resultant brown solid was collected and washed with cold THF/hexane $(\sim 1: 5,50 \mathrm{~mL})$ and dried in vacuo. Crystals of $\mathbf{5}$ were obtained from a concentrated solution in DME stored at $-35{ }^{\circ} \mathrm{C}$ (Yield: $132 \mathrm{mg}, 0.13 \mathrm{mmol}, 38 \%$ ). When the reaction was attempted using Schlenk line techniques, small crops of $\left[\mathrm{K}(18 \text {-crown-6)(DME) }]_{2}\left[\left\{\mathrm{UO}_{2}\left(\mu-\mathrm{O}_{2}\right)\left(\mathrm{N}^{\prime \prime}\right)_{2}\right\}_{2}\right]\right.$ (6) were also isolated and characterized via single crystal XRD. The high thermal instability of $\mathbf{5}$ in solution precluded spectroscopic characterization. Anal. Calc'd (\%) for $\mathrm{C}_{60} \mathrm{H}_{144} \mathrm{~K}_{2} \mathrm{~N}_{8} \mathrm{O}_{16} \mathrm{Si}_{8} \mathrm{U}_{2}$ : C 35.80, H 7.21, N 5.57; found: C 35.22, H 7.12, N 5.07.

$\left[\{U(\mu-O))_{2}\left(N^{\prime \prime}\right)_{2}(\mu-C l)\right\}\left\{K(18 \text {-crown-6) }\}_{2}\right]$ (7). A Schlenk flask with a stirrer bar was charged with $4(0.735 \mathrm{~g}, 1 \mathrm{mmol})$. Additionally, a separate flask was charged with a mixture of 18-crown-6 $(0.529 \mathrm{~g}, 2$ $\mathrm{mmol}), \mathrm{KC}_{8}(0.137 \mathrm{~g}, 1 \mathrm{mmol})$ and $\mathrm{KCl}(0.087 \mathrm{~g}, 1.2 \mathrm{mmol})$. Both flasks were cooled to $-50{ }^{\circ} \mathrm{C}$ and DME ( $5 \mathrm{~mL}$ each) was added. Both mixtures were allowed to stir for $5 \mathrm{~min}$, at which point the slurry of 2.2.2-cryptand and $\mathrm{KC}_{8}$ was added quickly to the solution of 4 . More DME (ca. $5 \mathrm{~mL}$ ) was added in order to collect the rest of the $\mathrm{KC}_{8}$ slurry and complete the addition. The reaction was allowed to stir at $-50{ }^{\circ} \mathrm{C}$ for $5 \mathrm{~min}$ at which point stirring was stopped and the solution left to settle for $2 \mathrm{~min}$. The solution was then filtered into a precooled Schlenk flask $\left(-50{ }^{\circ} \mathrm{C}\right)$ affording an amber-brown solution. Subsequent concentration of the mother liquor to ca. $5 \mathrm{~mL}$ followed by layering with pentane $(7 \mathrm{~mL})$ and storage at $-25{ }^{\circ} \mathrm{C}$ lead to amber-brown crystals of 7 . Yield: $0.378 \mathrm{~g}, 0.38 \mathrm{mmol}, 38 \%) .{ }^{1} \mathrm{H}$ NMR 
Scheme 1. Synthesis of Uranyl(VI) Tris-amides, 2-crypt and 2-18C6, and Reduction to Monomeric Uranyl(V) Complexes 3crypt and 3-18C6
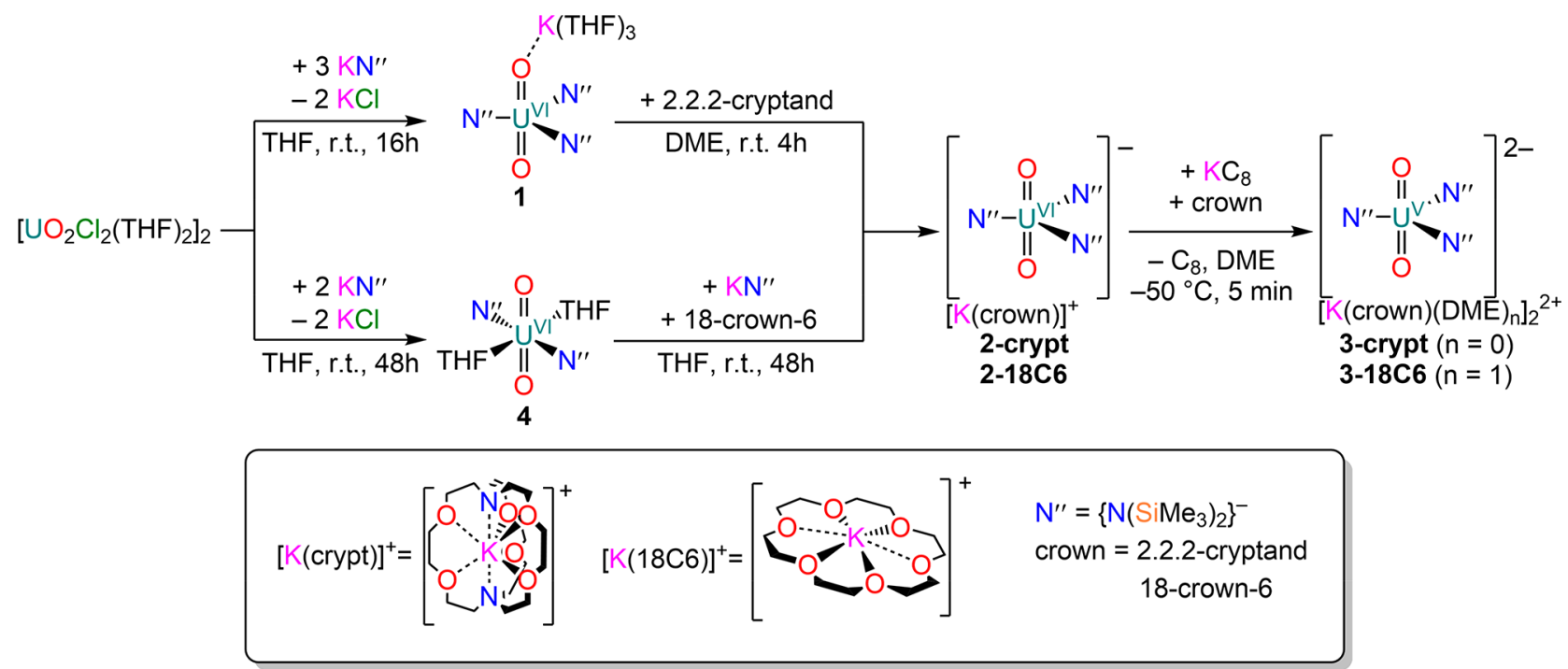

Scheme 2. Reduction of Uranyl(VI) Bis-amide 4 and to Dimeric Uranyl(V) Complex 5 and Monomeric Uranyl(V) Complex 7
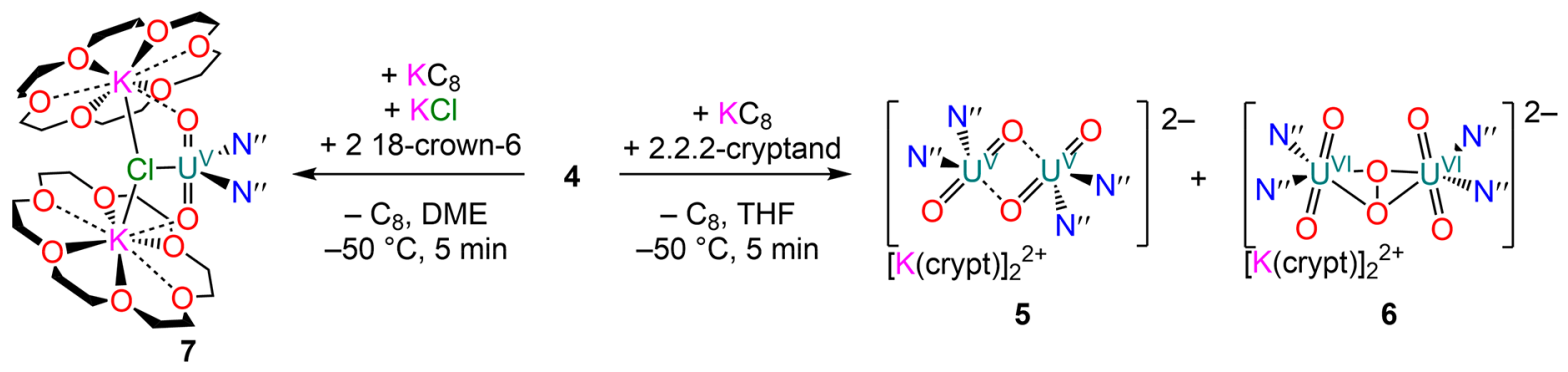

(tetrahydrofuran- $\left.d_{8}, 298 \mathrm{~K}\right) \delta-8.52\left(\mathrm{br}, \nu_{1 / 2}=55 \mathrm{~Hz}, \mathrm{Si}\left(\mathrm{CH}_{3}\right)_{3}, 5.18\right.$ (br, $\nu_{1 / 2}=51 \mathrm{~Hz}$, crown $\left.-\mathrm{CH}_{2}\right) \cdot{ }^{13} \mathrm{C}\left\{{ }^{1} \mathrm{H}\right\}$ NMR (tetrahydrofuran- $d_{8}$, $298 \mathrm{~K}) \delta 6.24\left(\mathrm{Si}\left(\mathrm{CH}_{3}\right)_{3}\right), 72.15$ (crown- $\left.\mathrm{CH}_{2}\right) .{ }^{29} \mathrm{Si}\left\{{ }^{1} \mathrm{H}\right\}$ NMR signal not observed. $\mu_{\text {eff }}$ (Evans method, $298 \mathrm{~K}$, tetrahydrofuran- $\left.d_{8}\right) 2.44 \mu_{\mathrm{B}}$. Anal. Calc'd (\%) for $\mathrm{C}_{36} \mathrm{H}_{84} \mathrm{ClK}_{2} \mathrm{~N}_{2} \mathrm{O}_{14} \mathrm{Si}_{4} \mathrm{U}$ : C 35.07, $\mathrm{H}$ 6.87, N 2.27; Found: C 35.44, H 7.08, N 2.17. FTIR (ATR microcrystalline) $\tilde{\nu}$ 2865 (br m), 1452 (w), 1352 (m), 1235 (m), 1103 (vs), 958 (s), 861 (m-shoulder, $\left.\mathrm{U}=\mathrm{O}_{(\mathrm{yl}) \text { asym }}\right), 821(\mathrm{~s}), 748(\mathrm{w}), 644(\mathrm{w}), 593(\mathrm{w})$ $\mathrm{cm}^{-1}$. Raman (solid, $638 \mathrm{~nm}, 10 \%$, smoothed) $\tilde{\nu} 2900$ (br, s), 1472(m), 1274(m), $1140(\mathrm{w}), 869(\mathrm{~m}), 784(\mathrm{br} \mathrm{s})\left(\mathrm{U}=\mathrm{O}_{(\mathrm{yl}) \mathrm{sym}}\right)$, $434(\mathrm{br} \mathrm{m}), 277(\mathrm{~m}) \mathrm{cm}^{-1}$. UV/vis $(5.63 \mathrm{mM}$, THF $) \lambda_{\max }\left(\varepsilon / \mathrm{mol}^{-1}\right.$ $\left.\mathrm{cm}^{-1}\right)$ : $841(54), 655(105), 495(250) \mathrm{nm}$.

\section{RESULTS AND DISCUSSION}

Synthesis and NMR Characterization. The sterically bulky bis(trimethylsilyl)amide ligand, $\left(\mathrm{N}\left(\mathrm{SiMe}_{3}\right)_{2}\right)^{-}$, $\left(\mathrm{N}^{\prime \prime}\right),{ }^{1-46}$ was selected to stabilize $\left[\mathrm{U}^{\mathrm{V}} \mathrm{O}_{2}\right]^{+}$complexes, since the ligands lack strongly absorbing chromophores. This approach has proven successful in enabling the identification and characterization of the optical properties of $\mathrm{U}^{4+}$, $\left[\mathrm{Np}^{\mathrm{V}} \mathrm{O}_{2}\right]^{+}$, and $\left[\mathrm{Np}^{\mathrm{VI}} \mathrm{O}_{2}\right]^{2+} \cdot{ }^{47}$ Uranyl(VI) silylamide complexes $\left[\mathrm{K}(\mathrm{THF})_{3}\right]\left[\mathrm{UO}_{2}\left(\mathrm{~N}^{\prime \prime}\right)_{3}(\mathrm{THF})\right]$ (1) and $\left[\mathrm{UO}_{2}\left(\mathrm{~N}^{\prime \prime}\right)_{2}(\mathrm{THF})\right](4)$ were synthesized via salt metathesis between $\left[\mathrm{UO}_{2}(\mathrm{Cl})_{2}(\mathrm{THF})_{2}\right]_{2}$ and ligand transfer reagent $\mathrm{KN}^{\prime \prime}$ in a $1: 3$ (Scheme 1) or 1:2 ratio (Scheme 2). Complex 1 was converted to $[\mathrm{K}($ crypt $)]\left[\mathrm{UO}_{2}\left(\mathrm{~N}^{\prime \prime}\right)_{3}\right]$ (2-crypt, crypt $=2.2 .2$ cryptand) by reaction with one equivalent of 2.2.2-cryptand, while the analogous complex $[\mathrm{K}(18 \mathrm{C} 6)]\left[\mathrm{UO}_{2}\left(\mathrm{~N}^{\prime \prime}\right)_{3}\right](2-$ 18C6, $18 \mathrm{C} 6=18$-crown-6) was obtained by reacting 4 with one equivalent of $\mathrm{KN}^{\prime \prime}$ and 18-crown-6. The monomeric
uranyl(V) derivatives $\left[\mathrm{K}(\mathrm{L})(\mathrm{DME})_{\mathrm{n}}\right]_{2}\left[\mathrm{UO}_{2}\left(\mathrm{~N}^{\prime \prime}\right)_{3}\right]$ (3-crypt, $\mathrm{L}$ = crypt, $n=0 ; 3-18 \mathrm{C} 6, \mathrm{~L}=18 \mathrm{C} 6, n=1)$ were obtained in moderate crystalline yields via reduction of 2-crypt or 2-18C6 with one equivalent of $\mathrm{KC}_{8}$ in the presence of corresponding sequestering agents (Scheme 1). When the reactions were carried out in the absence of sequestering agents, the only identifiable product was $\left[\mathrm{K}(\mathrm{DME})_{4}\right]\left[\mathrm{UO}_{2}\left(\mathrm{~N}^{\prime \prime}\right)_{3}\right]$. On the other hand, when the bis-amide precursor 4 was reduced with $\mathrm{KC}_{8}$ and 2.2.2-cryptand, the uranyl(V) dimer [K(crypt) $]_{2}\left[\left(\mathrm{UO}(\mu \text {-O })\left(\mathrm{N}^{\prime \prime}\right)_{2}\right)_{2}\right](5)$ was obtained in low yields (Scheme 2). The isolation of $\boldsymbol{5}$ is rather challenging, due to its inherent instability and the concomitant formation of the peroxo byproduct $[\mathrm{K}(\mathrm{crypt})]_{2}\left[\left(\mathrm{UO}_{2}\left(\mathrm{~N}^{\prime \prime}\right)_{2}\right)_{2}\left(\mu-\mathrm{O}_{2}\right)\right]$ (6). When the same reduction was attempted in the presence of 18-crown-6, the uranyl $(\mathrm{V})$ ate-complex $\left[\left(\mathrm{UO}_{2}\left(\mathrm{~N}^{\prime \prime}\right)_{2}\right)(\mu\right.$-Cl)$\left.(\mathrm{K}(18 \mathrm{C} 6))_{2}\right](7)$ was obtained; its formation was likely due to the presence of $\mathrm{KCl}$ in the starting material. Therefore its preparation was purposely attempted by reacting 4 with an equimolar ratio of $\mathrm{KCl}$ and 18 -crown-6, which resulted in the formation of 7 in moderate yields (Scheme 2). All compounds were thoroughly characterized via spectroscopic and analytical techniques, with the exception of $\mathbf{5}$ and 6: the former is a highly unstable compound which readily decomposes above $-30{ }^{\circ} \mathrm{C}$, while the latter was never isolated as an analytically pure species and has very low solubility in most laboratory solvents.

In comparison with the diamagnetic precursors 1 and 2, the ${ }^{1} \mathrm{H}$ NMR spectrum of 3-crypt displays a broadening of the 
spectral lines, which is in agreement with the presence of a paramagnetic metal center. Two resonances are identified for the $\mathrm{SiMe}_{3}$ protons $\left(\delta_{\mathrm{H}}=-8.47\right.$ and $\left.-4.77 \mathrm{ppm}\right)$, displaying a noticeable line broadening $\left(\delta_{\mathrm{H}}=-8.47 \mathrm{ppm}, \nu_{1 / 2}=60 \mathrm{~Hz} ; \delta_{\mathrm{H}}\right.$ $\left.=-4.75 \mathrm{ppm}, \nu_{1 / 2}=324 \mathrm{~Hz}\right)$. Additionally, three broad resonances each integrating for 24 protons are present in the downfield region of the spectrum $\left(\delta_{\mathrm{H}}=6.72 \mathrm{ppm}, \nu_{1 / 2}=24\right.$ $\mathrm{Hz} ; \delta_{\mathrm{H}}=8.17 \mathrm{ppm}, \nu_{1 / 2}=36 \mathrm{~Hz} ; \delta_{\mathrm{H}}=8.71 \mathrm{ppm}, \nu_{1 / 2}=40$ $\mathrm{Hz}$ ). It is noteworthy that 3-crypt displays a relatively high instability in solution at room temperature. After $48 \mathrm{~h}$, the decomposition is particularly enhanced and visible in the ${ }^{1} \mathrm{H}$ NMR spectrum, in conjunction with a significant shift of the 2.2.2-cryptand signals and the appearance of several other decomposition peaks (see SI, Figure S11).

The ${ }^{13} \mathrm{C}\left\{{ }^{1} \mathrm{H}\right\}$ NMR spectrum of 3-crypt displays characteristic resonances for the $\mathrm{SiMe}_{3}$ groups $\left(\delta_{\mathrm{C}}=6.39\right.$ and 7.09 ppm) and $\mathrm{CH}_{2}$ fragments belonging to the cryptand macrocycle $\left(\delta_{\mathrm{C}}=58.66,72.64\right.$, and $\left.75.90 \mathrm{ppm}\right) .{ }^{1} \mathrm{H}$ and ${ }^{13} \mathrm{C}\left\{{ }^{1} \mathrm{H}\right\}$ spectra of $3-\mathbf{1 8 C 6}$ are very similar to those of 3crypt, with different signals accounting for the presence of a different sequestering agent (18c6) and DME. Additionally, one signal was observed in the ${ }^{29} \mathrm{Si}\left\{{ }^{1} \mathrm{H}\right\}$ NMR spectra of both 3-crypt and 3-18C6, resonating at -103.12 and $-115.49 \mathrm{ppm}$ respectively.

The ${ }^{1} \mathrm{H}$ NMR spectrum of 7 displays two broad signals for the $\mathrm{SiMe}_{3}$ protons $\left(\delta_{\mathrm{H}}=-8.52 \mathrm{ppm}, \nu_{1 / 2}=55 \mathrm{~Hz}\right)$ and $\mathrm{CH}_{2}$ protons of the crown $\left(\delta_{\mathrm{H}}=-51 \mathrm{ppm}, \nu_{1 / 2}=51 \mathrm{~Hz}\right)$, with additional diamagnetic impurities similar to those observed for 3-crypt. The corresponding signals are also observed in the ${ }^{13} \mathrm{C}\left\{{ }^{1} \mathrm{H}\right\}$ NMR spectrum, with peaks resonating at 6.24 $\left(\mathrm{SiMe}_{3}\right)$ and 72.15 (18-crown-6). Unlike for 3-crypt and 318C6, no clear signal was visible in the ${ }^{29} \mathrm{Si}\left\{{ }^{1} \mathrm{H}\right\}$ NMR. Line broadening is typically observed in the ${ }^{1} \mathrm{H}$ and ${ }^{13} \mathrm{C}$ NMR spectra of $U(V)$ species. This is also detected in the ${ }^{1} \mathrm{H}$ NMR spectra of uranyl(V) species with various supporting ligands ${ }^{48-51}$ and bis-imido analogues, while ${ }^{13} \mathrm{C}$ data is rarely reported. ${ }^{52-54}$ Interestingly, full width half maxima of the ${ }^{1} \mathrm{H}$ NMR signals of 3 -crypt $\left(\nu_{1 / 2}\right.$ range $\left.=24-324 \mathrm{~Hz}\right)$ are significantly narrower than those observed in bis-imido complexes $\left[\mathrm{U}^{\mathrm{V}}(\mathrm{NDipp})_{2}\left(\mathrm{bipy}^{\mathrm{R} 2}\right)_{2}(\mathrm{X})\right]\left(\mathrm{Dipp}=2,6-{ }^{\mathrm{i}} \mathrm{Pr}_{2} \mathrm{C}_{6} \mathrm{H}_{2}\right.$; bipy $^{\mathrm{R} 2}=4,4^{\prime}$-dialkyl-2,2' -bipyridine; $\left.\mathrm{R}=\mathrm{Me},{ }^{\mathrm{t}} \mathrm{Bu} ; \mathrm{X}=\mathrm{Cl}, \mathrm{Br}, \mathrm{I}\right)$ $\left(\nu_{1 / 2}\right.$ range $\left.=154-2701 \mathrm{~Hz}\right) .^{53}$

Despite their instability in solution, we were able to determine the magnetic moment, $\mu_{\text {eff }}$ of 3-crypt and 3$18 \mathrm{C} 6$ at room temperature via the Evans method. ${ }^{55}$ These were measured at $2.45 \mu_{\mathrm{B}}$ and $2.67 \mu_{\mathrm{B}}$ respectively, thus falling within the range expected for monometallic $\mathrm{U}(\mathrm{V})^{56}$ and close to the predicted magnetic moment of the $\mathrm{U}^{5+}$ free ion $\left(\mu_{\mathrm{eff}}=\right.$ $\left.2.54 \mu_{\mathrm{B}}\right) .{ }^{57}$ Noticeably, the magnetic moment values obtained for 3-crypt and 3-18C6 are higher than those of other uranyl(V) species measured with similar methods, such as $\left[\mathrm{K}\left(18\right.\right.$-crown-6] $\left[\mathrm{UO}_{2}\left(\right.\right.$ salan- $\left.\left.^{\mathrm{t}} \mathrm{Bu}_{2}\right)(\mathrm{py})\right]$ and $[\mathrm{K}(18$-crown-6]$\left[\mathrm{UO}_{2}\left(\right.\right.$ salophen- $\left.\left.{ }^{\mathrm{t}} \mathrm{Bu}_{2}\right)(\mathrm{py}) \mathrm{K}\right]\left(\mu_{\text {eff }}=2.14-2.25 \mu_{\mathrm{B}}\right)$ reported by Mazzanti and co-workers ${ }^{50}$ - though it is noteworthy that the values reported by these authors are significantly lower than those obtained with solid state magnetic susceptibility measurements $\left(2.57-2.60 \mu_{\mathrm{B}}\right)$.

Structural Characterization. The identity of these complexes was established through single-crystal X-ray diffraction (SC-XRD) experiments, which demonstrated the formulation of the anionic $\left[\mathrm{UO}_{2} \mathrm{~N}_{3}{ }_{3}\right]^{2-}$ fragment with two cationic $[\mathrm{K}(\mathrm{L})]^{+}$counterions to balance the overall charge in 3-crypt and 3-18C6 and a trigonal bipyramid geometry around the metal center, close to that observed for precursors $\mathbf{1}^{34}$ and $\mathbf{2}$ (Figure 1 and S37-S39). ${ }^{34}$ The $\mathrm{U}=\mathrm{O}$ distances of

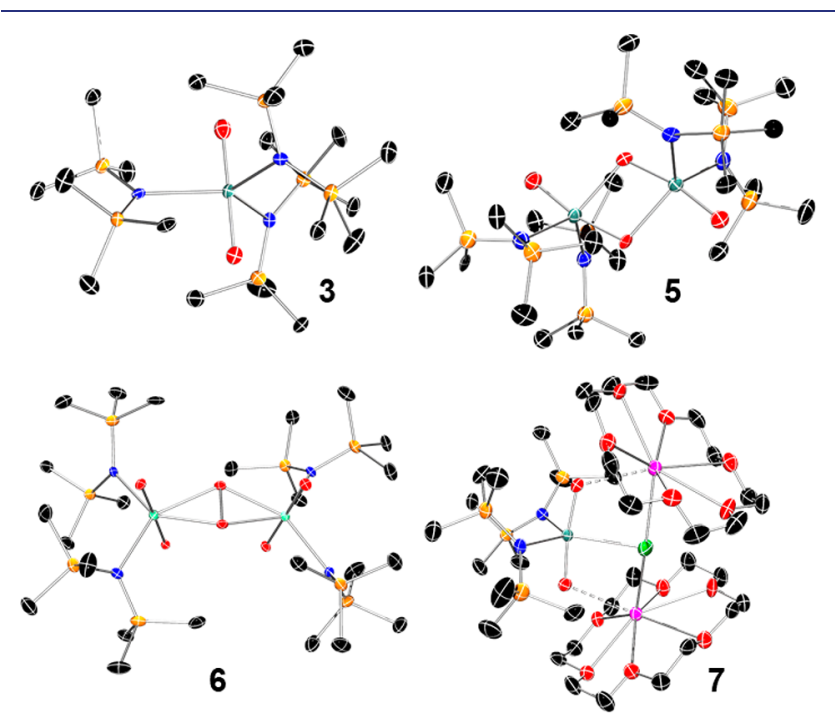

Figure 1. Molecular structures of 3-crypt, 5, 6, and 7 determined by SC-XRD. Thermal ellipsoids are shown at $50 \%$ probability for all structures. Hydrogen atoms and outer-sphere cations are omitted for clarity. Black, blue, red, orange, green, magenta and aqua represent carbon, nitrogen, oxygen, silicon, chlorine, potassium and uranium, respectively.

the $\left[\mathrm{U}^{\mathrm{V}} \mathrm{O}_{2}\right]^{+}$fragment in 3-crypt $[1.829(3)-1.843(3) \AA$ and 3-18C6 $[1.853(3)-1.855(3) \AA]$ are longer than those previously reported for monomeric $\left[\mathrm{U}^{\mathrm{V}} \mathrm{O}_{2}\right]^{+}$species $[1.736-$ $1.821 \AA]$ (Tables S4-S5) and may be a reflection of the strong sigma donating ability of the amide ligands. ${ }^{21,25}$ The $\left[\mathrm{U}^{\mathrm{V}} \mathrm{O}_{2}\right]^{+}$ fragment is perfectly linear in all polymorphs, together with a near perfect trigonal planar arrangement around the equatorial coordination plane. Slight elongations of the $\mathrm{U}-\mathrm{N}$ distances are also observed in 3-crypt $[2.430(3)-2.476(4) \AA]$ with respect to the $\left[\mathrm{U}^{\mathrm{VI}} \mathrm{O}_{2}\right]^{2+}$ precursors 1 and 2-crypt $[2.310(4)-$ 2.333(4) $\AA]$. This trend is in-line with changes in the ionic radii of the uranium ion. ${ }^{58}$ In the case of 7 , the $U=\mathrm{O}$ distances are statistically identical with those of 3-crypt and 318C6 $[1.846(5)-1.848(5) \AA]$, while the U-N bond lengths are shorter $[2.409(6)-2.412(6) \AA]$. Interestingly, the $\mathrm{O}=\mathrm{U}=$ O deviates slightly from linearity $\left[171.8^{\circ}(2)\right]$ owing to the interaction between $\mathrm{K}$ cations and the uranyl(V) unit.

Single crystals of 5 reveal two $\left[\mathrm{UO}_{2} \mathrm{~N}_{2}{ }_{2}\right]^{+}$fragments joined through a CCI, thereby forming an oxo-bridged dimer with diamond-shaped $\left[\mathrm{UO}_{2}\right]_{2}$ core $[\mathrm{U} \cdots \mathrm{O}=2.327(13)$ and $2.330(13) \AA]$ (Figure 1). Such a conformation is rare but has been previously observed in $\left[\mathrm{U}^{\mathrm{V}} \mathrm{O}_{2}\right]^{+}$species. ${ }^{17}$ Analogously to 3 , the $\mathrm{U}-\mathrm{O}$ distances in 5 are elongated $[1.868(13)-1.959(13) \AA]$ with respect to its $\left[\mathrm{U}^{\mathrm{VI}} \mathrm{O}_{2}\right]^{2+}$ precursor, 4, and both $\mathrm{O}=\mathrm{U}=\mathrm{O}$ units in the dimer are significantly bent $[168.5(7)$ and $168.8(7)]$. Additionally, the distances of the terminal $\mathrm{U}-\mathrm{O}$ interactions $[1.940$ (13) and $1.959(13) \AA]$ are significantly shorter than those bridging between the two $\left[\mathrm{U}^{\mathrm{V}} \mathrm{O}_{2}\right]^{+}$. In contrast to previously reported examples, in which the CCI was favored by additional interactions of the actinyl fragment, ${ }^{25,29,59}$ the formation of the diamond-shaped core in $\mathbf{5}$ is unsupported.

Electronic Structure Investigation and Analysis. The UV-vis-nIR absorption spectra of 3-crypt in DME further demonstrate the presence of pentavalent uranyl (Figure 2A). 

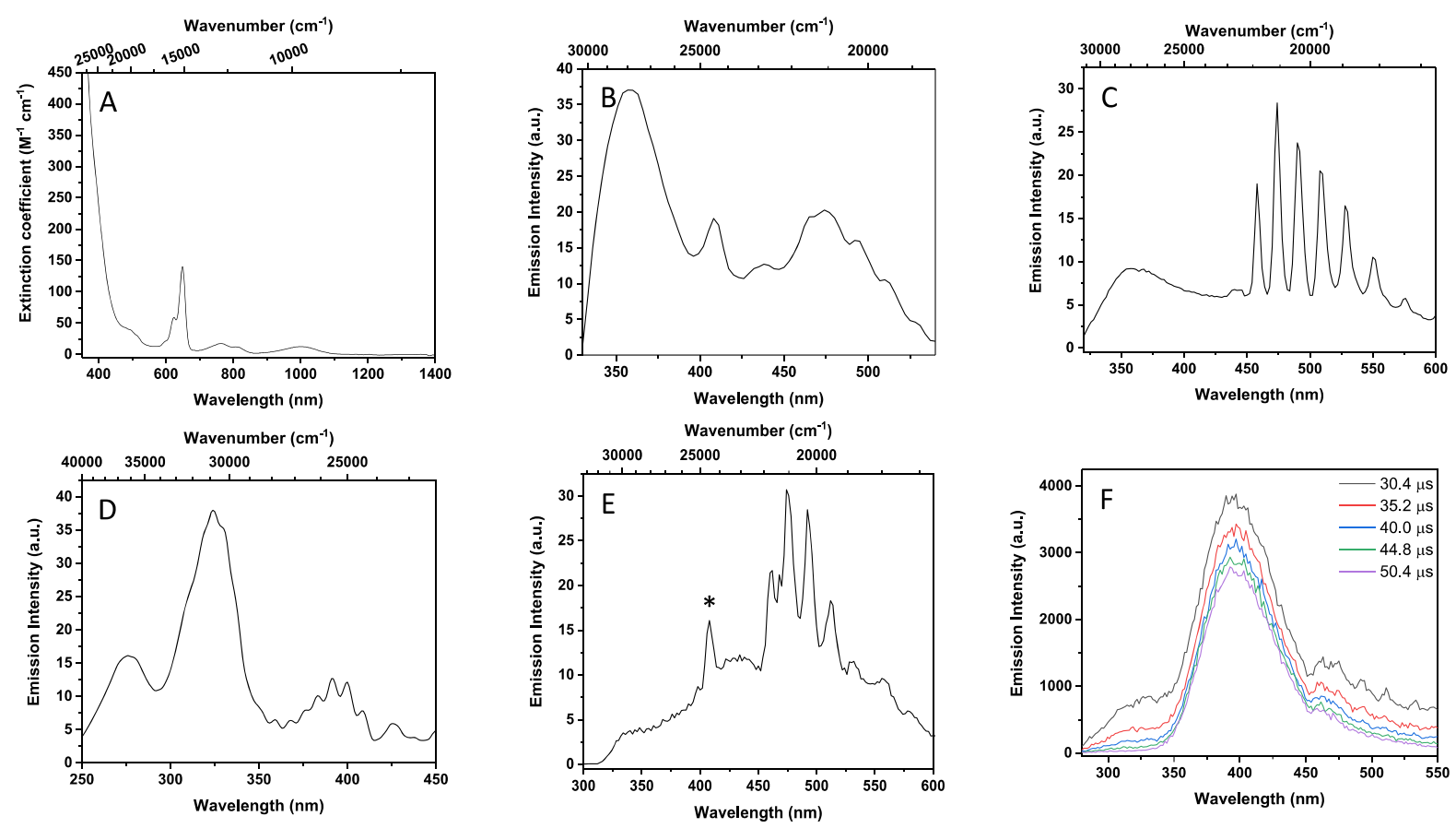

Figure 2. Representative spectra of 3-crypt: (A). Electronic UV-vis-nIR absorption spectrum (2.9 mM, DME). (B) Corrected steady state emission spectrum recorded $\left(295 \mathrm{~K}, 2-\mathrm{Me}-\mathrm{THF}, \lambda_{\mathrm{exc}}=280 \mathrm{~nm}\right)$. (C) Corrected steady state emission spectrum recorded at $77 \mathrm{~K}$ (frozen $2-\mathrm{Me}-$ $\mathrm{THF}, \lambda_{\mathrm{exc}}=300 \mathrm{~nm}$ ). (D) Corrected excitation spectrum recorded at $77 \mathrm{~K}$ (frozen 2-Me-THF, $\lambda_{\mathrm{em}}=475 \mathrm{~nm}$ ). (E) Corrected steady state emission spectrum of ground powder recorded $\left(295 \mathrm{~K}, \lambda_{\text {exc }}=280 \mathrm{~nm}\right)$. * denotes scattered light. (F) Spectrally sliced time-resolved emission spectra (Figure S51) of powdered 3-crypt (295 K, $230 \mathrm{~nm}$ excitation, recorded over a $400 \mu$ s time domain).

The spectrum shows a broad, intense feature centered at $v_{\max }=$ $22000 \mathrm{~cm}^{-1}$ extending to higher energies, plus a series of sharper electronic transitions at approximately 15600,13300 , 12500,10000 , and $1440 \mathrm{~cm}^{-1}\left(\lambda_{\max }=641\left(\varepsilon=145 \mathrm{M}^{-1}\right.\right.$ $\left.\left.\mathrm{cm}^{-1}\right)\right), 752\left(\varepsilon=20 \mathrm{M}^{-1} \mathrm{~cm}^{-1}\right), 800\left(\varepsilon=15 \mathrm{M}^{-1} \mathrm{~cm}^{-1}\right), 1000$ $\left(\varepsilon=15 \mathrm{M}^{-1} \mathrm{~cm}^{-1}\right)$ and $\left.6944\left(\varepsilon=145 \mathrm{M}^{-1} \mathrm{~cm}^{-1}\right) \mathrm{nm}\right)$ at lower energies (Figure S41 and S42 (SI)). These transitions are assigned as admixtures of $5 \mathrm{f} \leftarrow \mathrm{U}=\mathrm{O}_{(\mathrm{yl})}$, $5 \mathrm{f} \leftarrow$ amide, intraligand, intra $5 \mathrm{f}, 6 \mathrm{~d} \leftarrow 5 \mathrm{f}$, and $7 \mathrm{~s} \leftarrow 5 \mathrm{f}$ transitions by comparison with the calculated excitations in 3-crypt (see Figure S80 and Table S6, SI for full assignments). In comparison with experimental findings on related systems ${ }^{30}$ and theoretical calculations for the bare $\left[\mathrm{UO}_{2}\right]^{+}$ion, ${ }^{61,64-69}$ the excitations can be approximately assigned as transitions involving the $\sigma_{\mathrm{u}} \varphi_{\mathrm{u}} \delta_{\mathrm{u}}\left(15600 \mathrm{~cm}^{-1}\right), \sigma_{\mathrm{u}}^{2} \pi_{\mathrm{u}}^{*}\left(13300 \mathrm{~cm}^{-1}\right)$, $\sigma_{\mathrm{u}}^{2} \pi^{*}{ }_{\mathrm{u}} / \sigma_{\mathrm{u}}^{2} \varphi_{\mathrm{u}} / \sigma_{\mathrm{u}}^{2} \delta_{\mathrm{u}}\left(12500 \mathrm{~cm}^{-1} / 10000 \mathrm{~cm}^{-1}\right)$ electronic configurations (Figure 3).

Solvatochromism of 3-crypt is further evidence the chargetransfer character of absorptions in the visible region: dissolution in pyridine converges the energies of the visible and nIR absorption bands that span the 16000 to $9000 \mathrm{~cm}^{-1}$ range $(625-1110 \mathrm{~nm}$, see Figure S42 (SI)).

The diagnostic spectroscopic features of $\left[\mathrm{U}^{\mathrm{V}} \mathrm{O}_{2}\right]^{+}$were further defined via vibrational spectroscopy, including the first reported Raman spectra for well-defined molecular pentavalent uranyl species. Solid-state Raman spectra of $\mathbf{1}$ and 2-crypt have been previously reported with $\mathrm{U}=\mathrm{O}_{(\mathrm{yl})}$ symmetric stretching modes at 802 and $809 \mathrm{~cm}^{-1}$, respectively. A progression is often observed with the archetypal uranyl(VI) $\sigma_{\mathrm{u}} \leftarrow \delta_{\mathrm{u}} /$ $\varphi_{\mathrm{u}} \mathrm{LMCT}$ emission $\left(\leftarrow \lambda_{\max } \sim 510 \mathrm{~nm}\right)$. In the solid-state Raman spectrum of 3-crypt several signals are observed (Figure S25), including the equivalent $\mathrm{U}=\mathrm{O}_{(\mathrm{yl})}$ symmetric stretching mode at $753 \mathrm{~cm}^{-1}$ in THF solution, with a shoulder peaking between 682 and $697 \mathrm{~cm}^{-1}$ (this feature is resolved in 3-18C6 at $\left.727 \mathrm{~cm}^{-1}\right)$. The shift of the $\nu_{1}\left(\mathrm{U}=\mathrm{O}_{(\mathrm{yl})}\right)$ symmetric stretch between $\left[\mathrm{U}^{\mathrm{VI}} \mathrm{O}_{2}\right]^{2+}$ and $\left[\mathrm{U}^{\mathrm{V}} \mathrm{O}_{2}\right]^{+}$species is consistent with a decrease in the nuclear charge at uranium. This effect can also be quantified by calculating the relative stretching and interaction force constants $\left(k_{1} \text { and } k_{12}\right)^{34,70,71}$ The uranyl(VI) precursors 2-18C6 and 2-crypt have stretching force constants of 6.85 and 6.94 mdyn $\AA^{-1}$ respectively. As expected, the force constants decrease for 3-18C6 and 3-crypt and are measured at 5.66 and $5.53 \mathrm{mdyn}$ $\AA^{-1}$, respectively. ${ }^{72}$ These experimental spectra are wellreproduced by DFT calculations (geometry optimization and vibrational analysis, Figure S81).

This vibrational analysis sets the stage for the detailed understanding of the photoluminescence spectra. ${ }^{62,63}$ Prior to this work, observation of uranyl(V) species has thus far been limited to in situ studies of species generated from uranyl(VI). ${ }^{31,32}$ In both instances, emission spectroscopy revealed broad featureless emission bands centered at 405 and $440 \mathrm{~nm}$ respectively following $255 \mathrm{~nm}$ excitation. with luminescence lifetimes attributed to uranyl(V) carbonate emission of $140 \mu \mathrm{s}$

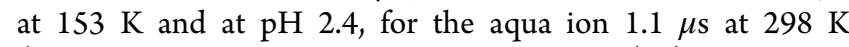
(compared to $0.9 \mu \mathrm{s}$ for the equivalent uranyl(VI) species also present in the solution at room temperature).

Very recently, Mazzanti and co-workers reported the emission properties of a water-soluble uranyl(V) dipicolinic acid (dpa) complex $[\mathrm{K}(2 \cdot 2.2 . \mathrm{crypt})]_{2 n}\left\{\left[\mathrm{KUO}_{2}(\mathrm{dpa})_{2}\right]\right\} .{ }^{18}$ in this system, the emission spectrum exhibits a broad profile with two maxima at 404 and $459 \mathrm{~nm}$ following excitation at $360 \mathrm{~nm}$, with corresponding excitation peaks for the $404 \mathrm{~nm}$ emission band at 335 and $360 \mathrm{~nm}$. Upon excitation at $459 \mathrm{~nm}$, the second maxima is shifted to lower energy. At low temperatures $(77 \mathrm{~K})$, it was observed that the emission profile becomes well 


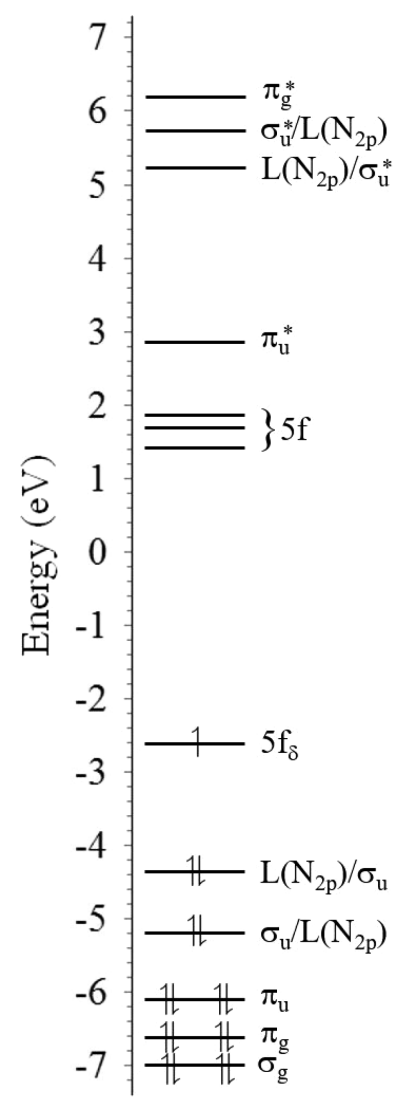

Figure 3. Computed MO diagram of 3-crypt in the ground state. For clarity, ligand orbitals are not explicitly shown. The principal excitation promotes an electron from the $\sigma_{\mathrm{u}} / \mathrm{L}\left(\mathrm{N}_{2 \mathrm{p}}\right)$ to the $5 \mathrm{f} \delta_{\mathrm{u}}$ orbital(s) (labeled as $5 \mathrm{f}$ above, leaving an unpaired electron in the $\sigma_{\mathrm{u}}$ Sf $\delta_{\delta}$, and $5 \mathrm{f} \delta_{\mathrm{u}}$ orbitals).

resolved with seven distinguishable vibrationally resolved lines in addition to lower intensity vibrationally resolved emission up to $550 \mathrm{~nm}$; the excitation spectra also exhibit four sharp lines centered at ca. $360 \mathrm{~nm}$. The decay kinetics showed bi- or multiexponential behavior, with the longest component resolved as $11 \mu \mathrm{s}$. These data are broadly in agreement with those observed for 3-crypt reported herein.

The photophysical properties of the uranyl(VI) tris amide precursor, 2-crypt, $[\mathrm{K}(2.2 .2$-cryptand $)]\left[\mathrm{UO}_{2}\left\{\mathrm{~N}\left(\mathrm{SiMe}_{3}\right)_{2}\right\}_{3}\right]$ are shown in Figures S56-S60. The principal peak positions in the emission spectrum are typical of uranyl(VI) and are 528 $\mathrm{nm}\left(18939 \mathrm{~cm}^{-1}\right), 550 \mathrm{~nm}\left(18797 \mathrm{~cm}^{-1}\right), 554 \mathrm{~nm}(18182$ $\left.\mathrm{cm}^{-1}\right), 576 \mathrm{~nm}\left(17361 \mathrm{~cm}^{-1}\right)$, with vibrational spacings measured as 757 and $821 \mathrm{~cm}^{-1}$. Here, the emission maximum is significantly red-shifted $(550 \mathrm{~nm})$ compared to aqueous uranyl salts (ca. $510-520 \mathrm{~nm}$ ) due to the strong amide sigma donors located in the equatorial plane. ${ }^{33,47}$

Continuous-wave UV excitation (230-300 nm) of $\mathrm{mM}$, room temperature DME, THF and 2-Me-THF solutions of 3crypt (Figure 2B) results in broad emission spectra, which are comprised of two principal bands centered at 355 and $475 \mathrm{~nm}$ (26 170 and $21050 \mathrm{~cm}^{-1}$ ). In room temperature 2-Me-THF, the $475 \mathrm{~nm}$-feature displays discernible vibrational progression. Upon freezing to a glass at $77 \mathrm{~K}$ in $2-\mathrm{Me}-\mathrm{THF}$, this vibrational fine structure becomes pronounced revealing seven vibronic transitions with peak-to-peak separations of 737, 772, 717, 669, 757 , and $760 \mathrm{~cm}^{-1}$ (average $=735 \mathrm{~cm}^{-1}$, Figure 2C). The apparent zero-phonon $\left(E_{0-0}\right)$ transition estimated between the first and second highest energy vibronic transitions at 737 $\mathrm{cm}^{-1}$ matches well with the $\mathrm{U}=\mathrm{O}_{(\mathrm{yl})}$ symmetric stretch measured experimentally by Raman spectroscopy $\left(753 \mathrm{~cm}^{-1}\right)$ and predicted computationally $\left(711 \mathrm{~cm}^{-1}\right)$ for the modes that possesses the most symmetric $\mathrm{U}=\mathrm{O}_{(\mathrm{yl})}$ stretching character. However, this vibration also possesses a degree of U$\mathrm{N}\left\{(\mathrm{SiMe})_{3}\right\}_{2}$ character, and computational analysis suggests that all of the other vibrations with symmetric stretching character are coupled to other molecular motions (723, 725, 728 , and $\left.732 \mathrm{~cm}^{-1}\right)$. The amide $\mathrm{N}-(\mathrm{SiMe})_{3}$ vibrations contribute to the vibrations at frequencies of 724,728 , and $736 \mathrm{~cm}^{-1}$, where the latter is the most pronounced. ${ }^{60,61}$ Therefore, more than one vibrational progression may be contributing to the spectrum.

The excitation spectra of 3-crypt (frozen 2-Me-THF) monitored at the lowest energy emission maximum (475 $\mathrm{nm})$ reveal three separate excitation regions centered at 275 , 324, and $390 \mathrm{~nm}$ (Figure 2D), whereas an excitation band at $220 \mathrm{~nm}$ is responsible for the emission at $355 \mathrm{~nm}$. In the excitation spectrum, the lower energy absorptions appear to exhibit vibrational fine structure. This feature is particularly pronounced in the lowest energy excitation band $(390 \mathrm{~nm})$, with six measurable maxima (frequency difference between the two lowest energy peaks is $490 \mathrm{~cm}^{-1}$, average peak-to-peak separation, $533 \mathrm{~cm}^{-1}$ ). These features are reminiscent of the vibrationally resolved LMCT absorptions exhibited in many $\left[\mathrm{U}^{\mathrm{VI}} \mathrm{O}_{2}\right]^{2+}$ compounds, but here may, in principle, arise from the multiple different excitations predicted in this region (Figure S80 and Table S6).

The luminescence lifetimes recorded at the emission maxima $(475 \mathrm{~nm})$ of 3-crypt in a frozen glass at $77 \mathrm{~K}$ (Figure $2 \mathrm{C}$ and Figure S44, Table 1) are biexponential with the short component resolved as $1.02 \mu \mathrm{s}(25 \%)$, and the longer one at $8.22 \mu \mathrm{s}(75 \%)$. This observation implies that there are several excited states contributing to the observed emission (as supported by theory). At room temperature ( $295 \mathrm{~K}$ ), the corresponding lifetimes of the $475 \mathrm{~nm}$ band are much shorter (2.1 and $9.5 \mathrm{ns)}$ and could only be measured accurately following pulsed picosecond excitation $(375 \mathrm{~nm})$.

To forestall contribution of any dynamic exchange and speciation effects, the optical properties of solid-state 3-crypt were examined in detail. The steady-state spectrum of 3-crypt as a powdered sample ( $295 \mathrm{~K}$ ), (Figure $2 \mathrm{E}$ ) shows a similar emission profile to those recorded in fluid solution and in a frozen glass, with overlapping broad features $\left(\lambda_{\mathrm{em}}=320,420\right.$, and $475 \mathrm{~nm}$ ). Again, the emission band at $475 \mathrm{~nm}$ appears to exhibit vibrational progression, where the estimated $E_{0-0}$ is 772 $\mathrm{cm}^{-1}$ (average $=743 \mathrm{~cm}^{-1}$ ). The kinetic profiles were also investigated by time-resolved emission spectroscopy (TRES, Figure 2F, S51). Notably, as a function of delay time, the emission profile of the $475 \mathrm{~nm}$ band resolves into two components with peak maxima at 400 and $475 \mathrm{~nm}$. The longest-lived of these emission profiles is centered at $475 \mathrm{~nm}$ and exhibits biexponential decay behavior $\left(\tau_{1}=4.31 \mu \mathrm{s}(12 \%)\right.$ and $\left.\tau_{2}=127 \mu \mathrm{s}(88 \%)\right)$, whereas the emissive feature at 400 $\mathrm{nm}$ is vibrationally broadened and is also modeled with a biexponential decay function $\left(\tau_{1}=5.56 \mu \mathrm{s}(2 \%), \tau_{2}=117 \mu \mathrm{s}\right.$ $(82 \%))$.

By analogy with reported experimental and theoretical data of uranyl(V) ${ }^{19,20,64,73}$ and neptunyl(VI) ${ }^{47} 5 \mathrm{f}^{1}$ species (where the emission with $\mathrm{An}=\mathrm{O}_{(\mathrm{yl})}$ to actinide charge transfer character has been observed at 405, 440, and $438 \mathrm{~nm}$ respectively in experiments), the equivalent lowest energy $\mathrm{U} \leftarrow$ 
Table 1. Summary of Lifetime Data for 2-Crypt, 3-Crypt, 5, and $7^{a}$

\begin{tabular}{|c|c|c|c|c|c|c|}
\hline complex & $\begin{array}{c}\lambda_{\mathrm{ex}} \\
(\mathrm{nm})\end{array}$ & $\begin{array}{c}\lambda_{\mathrm{em}} \\
(\mathrm{nm})\end{array}$ & $\begin{array}{c}\tau_{1}(\mu \mathrm{s}) / \\
(\%)\end{array}$ & $\begin{array}{c}\tau_{2}(\mu \mathrm{s}) / \\
(\%)\end{array}$ & $\begin{array}{c}\tau_{3}(\mu \mathrm{s}) / \\
(\%)\end{array}$ & $\chi^{2}$ \\
\hline 2 -crypt ${ }^{b}$ & 250 & 550 & $\begin{array}{l}5.9 \\
(34)\end{array}$ & $\begin{array}{l}40.8 \\
(37)\end{array}$ & $\begin{array}{l}176.7 \\
(27)\end{array}$ & 1.6 \\
\hline \multirow[t]{4}{*}{3 -crypt ${ }^{b}$} & 280 & 320 & $\begin{array}{l}3.7 \\
(56)\end{array}$ & $\begin{array}{l}24.0 \\
(44)\end{array}$ & $\begin{array}{l}186.4 \\
(29)\end{array}$ & 1.3 \\
\hline & 280 & 360 & $\begin{array}{l}4.3 \\
(12)\end{array}$ & $\begin{array}{l}77.5 \\
(51)\end{array}$ & $\begin{array}{l}153.3 \\
(36)\end{array}$ & 1.2 \\
\hline & 280 & 492 & $\begin{array}{l}5.2 \\
(11)\end{array}$ & $\begin{array}{l}41.2 \\
(31)\end{array}$ & $\begin{array}{l}204.1 \\
(58)\end{array}$ & 1.0 \\
\hline & 280 & 580 & $\begin{array}{l}6.9 \\
(11)\end{array}$ & $\begin{array}{l}44.2 \\
(36)\end{array}$ & $\begin{array}{l}198.7 \\
(53)\end{array}$ & 1.3 \\
\hline \multirow[t]{2}{*}{ 3-crypt ${ }^{c}$} & 300 & 420 & $\begin{array}{l}1.7 \\
(47)\end{array}$ & $\begin{array}{l}7.1 \\
(53)\end{array}$ & - & 1.2 \\
\hline & 300 & 475 & $\begin{array}{l}1.02 \\
(25)\end{array}$ & $\begin{array}{l}8.22 \\
(75)\end{array}$ & - & 1.3 \\
\hline \multirow[t]{3}{*}{$5^{b}$} & 230 & 370 & $\begin{array}{l}109.5 \\
(100)\end{array}$ & - & - & 1.3 \\
\hline & 230 & 440 & $\begin{array}{l}130.1 \\
(100)\end{array}$ & - & - & 1.2 \\
\hline & 230 & 550 & $\begin{array}{l}5.2 \\
(1)\end{array}$ & $\begin{array}{l}57.4 \\
(9)\end{array}$ & $\begin{array}{l}160.5 \\
(90)\end{array}$ & 1.0 \\
\hline \multirow[t]{3}{*}{$5^{c}$} & 260 & 430 & $\begin{array}{l}1.0 \\
(22)\end{array}$ & $\begin{array}{l}8.2 \\
(78)\end{array}$ & - & 2.1 \\
\hline & 260 & 535 & $\begin{array}{l}55.1 \\
(28)\end{array}$ & $\begin{array}{l}148.0 \\
(72)\end{array}$ & - & 1.1 \\
\hline & 260 & 590 & $\begin{array}{l}51.9 \\
(27)\end{array}$ & $\begin{array}{l}139.2 \\
(73)\end{array}$ & - & 1.3 \\
\hline \multirow[t]{2}{*}{$7^{c}$} & 325 & 480 & $\begin{array}{l}11.0 \\
(10)\end{array}$ & $\begin{array}{l}102.9 \\
(90)\end{array}$ & - & 1.1 \\
\hline & 325 & 550 & $\begin{array}{l}45.6 \\
(78)\end{array}$ & $\begin{array}{l}202.5 \\
(32)\end{array}$ & - & 1.2 \\
\hline
\end{tabular}

${ }^{a}$ Estimated error $\pm 10 \% .{ }^{b}$ Sample measured at $295 \mathrm{~K}$ in the solid state. ${ }^{c}$ Sample measured at $77 \mathrm{~K}$ in a frozen 2-Me-thf glass.

$\mathrm{U}=\mathrm{O}_{(\mathrm{yl})}$ LMCT transition is expected to lie in the UV and be blue-shifted with respect to that in uranyl(VI). In a complex of pseudo $D_{3 h}$ symmetry, as in $2(\mathrm{~L})$ and $3(\mathrm{~L})$, this transition is predicted to be formally Laporte-forbidden but may be relaxed in part with respect to the free ion of higher symmetry $\left(D_{\infty h}\right)$ due to the removal of the inversion symmetry by the inclusion of the equatorial ligands. For comparison, in the neptunyl(VI) complex $\left[\mathrm{NpO}_{2}(\mathrm{TPIP})_{2}\left(\mathrm{Ph}_{3} \mathrm{PO}\right)\right](\mathrm{TPIP}=$ tetraphenylimidodiphoshinate) ${ }^{47}$ the visible LMCT emission centered at 438 $\mathrm{nm}$ also exhibits vibrational fine structure that corresponds to a $\mathrm{N}-\mathrm{P}$ vibration. The electronic excitations responsible for this emission were shown by analogous calculations to be combination of $\mathrm{Np} \leftarrow$ TPIP and $\mathrm{Np} \leftarrow \mathrm{O}_{(\mathrm{yl})}$ LMCT charge transfer.

To investigate the origin of the emission in 3-crypt further, TD-DFT calculations were performed using linear response theory in the absence of point group symmetry, and a total of 100 excited states were evaluated. In preliminary studies to benchmark methods on free uranyl including hybrid-GGA (e.g., PBE0, B3LYP) and Coulomb-attenuated hybrids (e.g., CAM-B3LYP) with wave functions based methods (CASPT2) indicate little variation with respect to functional, ${ }^{74-79}$ and hence PBE0 was selected in an effort to minimize dependence of the simulation data on parameters not optimized for the system of interest. From a computational perspective, f-f transitions were assigned on the basis of visual inspection of electron density difference plots between ground and excited states (Figure 4).
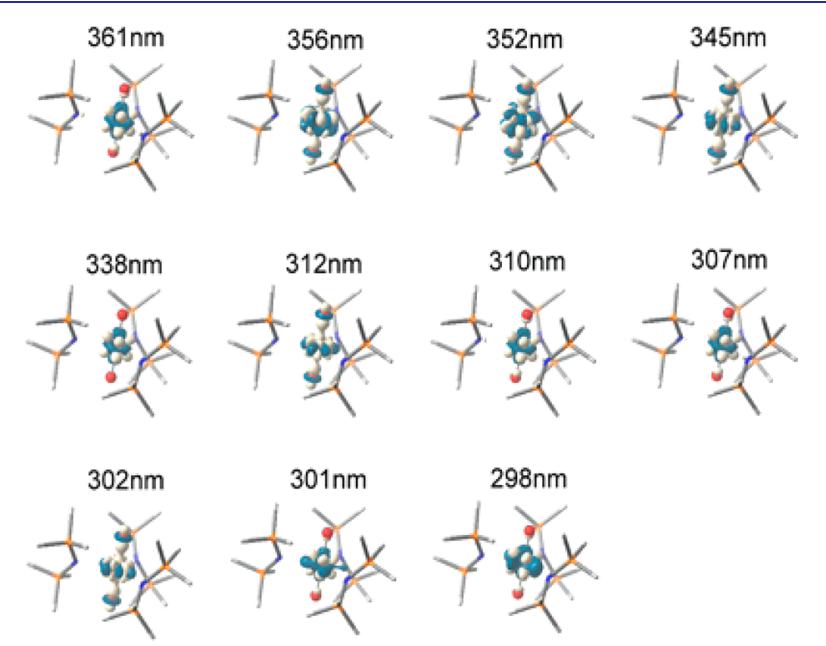

Figure 4. Plot of density differences between the ground and excited state for the 3-crypt. There are transitions with $\mathrm{O}_{(\mathrm{yl})}-\mathrm{f}$ character at $356,352,345,312$, and $302 \mathrm{~nm}$. The light regions indicate charge depletion and the blue areas charge accumulation.

Indeed, for the bare uranyl(VI) ion in the gas phase, our DFT simulations (PBE0/def2-TZVP) show the triplet state with single occupation of the $5 \mathrm{f} \delta_{\mathrm{u}}$ orbital (a fair approximation to the optically accessible excited state), ${ }^{80}$ whereas for the $\operatorname{uranyl}(\mathrm{V})$ cation, the equivalent excitation produces a quartet with occupation of each of the degenerate $5 \mathrm{f} \delta_{\mathrm{u}}$ orbitals. In both cases, the $\sigma_{\mathrm{u}}$ orbital has been deoccupied (Figure 4). The energy difference between these LMCT excitations are calculated as $2.29 \mathrm{eV}\left(18484 \mathrm{~cm}^{-1}, 541 \mathrm{~nm}\right)$ for uranyl(VI) and $2.82 \mathrm{eV}\left(22779 \mathrm{~cm}^{-1}, 439 \mathrm{~nm}\right)$ for uranyl(V) consistent with previous observations. ${ }^{20,31,32,64}$

Time-dependent DFT simulations of the excited states of 3crypt show numerous excitations between 200-300 nm with oscillator strengths $>10^{-3}$ (Figure 4, Table S6). Of these, a number of excitations with $5 \mathrm{f} \leftarrow \mathrm{O}_{\mathrm{yl}}$ character $(356,352,345$, $312,302 \mathrm{~nm}$ ) were identified (Figure S80). Energetically, these are not well separated from the intra $\mathrm{f}-\mathrm{f}$ transitions and oscillator strengths of all are typically $\sim 10^{-4}$. Higher energy excitations $<45450 \mathrm{~cm}^{-1}(220 \mathrm{~nm})$ are characterized as being localized on the amide ligands, while those between 220 and $265 \mathrm{~nm}$ are associated with charge-transfer from the amide ligands to the uranium nonbonding $5 \mathrm{f} \delta_{\mathrm{u}}$ orbitals.

Attempts to investigate the luminescence properties of 3$18 \mathrm{C} 6$ by excitation into the UV and visible absorption bands (220-650 nm), in both solution (2-Me-THF, DME) and in the solid state were unsuccessful, with no discernible emission or excitation seen even at $77 \mathrm{~K}$. This is in stark contrast to 3crypt. The lack of detectable emission under the same conditions in 3-18C6 may suggest that this complex is not as thermally and/or photochemically stable as 3-crypt and rapidly reacts or decomposes to form a nonemissive (or dark) thermal or photoproduct. Indeed, this difference in stability was observed by ${ }^{1} \mathrm{H}$ NMR spectroscopy as noted above. Very similar observations were seen in the luminescence experiments of the uranyl(VI) peroxo complex 6 (Figure S76).

The emission properties of the uranyl(V) complexes 5 and 7 , were also investigated, where we anticipated that any $\mathrm{U}=$ 
$\mathrm{O}_{(\mathrm{yl})}$ LMCT emission bands in particular would be red-shifted slightly compared to 3-crypt due to elongation/disruption of the linear uranyl unit. ${ }^{13}$ For dimeric 5, the spectra are broader than in 3-crypt in frozen solution and the solid state following UV excitation (280-360 nm), with peak maxima at ca. 370, 410, and $480 \mathrm{~nm}$ at 295 and $77 \mathrm{~K}$ (Figures S61-S75). The instability of $\mathbf{5}$ in optically dilute solutions and in the solid state over prolonged acquisition times precluded accurate and full data collection in addition to any data collection in fluid solution at room temperature. However, representative spectra in frozen solution at $77 \mathrm{~K}$ and in the solid state (Figures S61S75) exhibit features attributable to uranyl(V) centered around $470 \mathrm{~nm}$, albeit much broader as expected. There is also evidence for relatively stronger emission at higher energies (ca. $400 \mathrm{~nm}$ ) in line with that observed for 3-crypt. Nevertheless, the steady state emission spectra of $\mathbf{5}$ points toward the fact that higher nuclearity complexes of uranyl(V) may be observable by optical spectroscopy and show a unique spectral and temporal profile, especially when recorded at lower temperatures.

Finally for complex, 7, the emission spectrum (Figures S77S79) appears to be a combination of uranyl(V) and uranyl(VI), where typical uranyl(VI) emission bands (ca. $530 \mathrm{~nm})$ displaying vibrational fine structure $\left(E_{0-0}=769\right.$ $\mathrm{cm}^{-1}$ ) alongside a broader feature centered at ca. $480 \mathrm{~nm}$. However, the origin of this emission is not clear by examining the excitation spectra, and may be a result of uranyl(VI) LMCT from the equatorial amide/chloride donors or a mixture of uranyl(VI) LMCT and uranyl(V) LMCT emission.

Of note, we observed no emission in the near-infrared region of the electromagnetic spectrum with our current instrumentation by exciting across the UV-visible spectrum (300-850 $\mathrm{nm})$. This result is in contrast to the near-infrared emission observed from $\mathrm{NpO}_{2}^{2+}$ in $\mathrm{D}_{2} \mathrm{O}$ and in the polyoxometalate complex $\left[\mathrm{Na}_{2}\left(\mathrm{~Np}^{\mathrm{VI}} \mathrm{O}_{2}\right)_{2}\left(\mathrm{GeW}_{9} \mathrm{O}_{34}\right)_{2}\right]^{14-}$ reported by Faulkner and co-workers. ${ }^{72}$ Here, emission between 1452 and $1580 \mathrm{~nm}$ was observed following ns pulsed laser excitation at $337 \mathrm{~nm}$ $\left(\mathrm{N}_{2}\right.$ laser). This difference may be rationalized at least in part, by examining the respective absorption spectra, where there is a larger energy gap between the UV-visible absorptions (neptunyl(VI) LMCT and the polyoxometalate LMCT which acts to sensitize the emission in the complex) and the nearinfrared absorption at ca. $1230 \mathrm{~nm}$ which is the characteristic absorption and assigned as an interconfigurational 5f-f transition of neptunyl(VI); i.e., they are more energetically well separated. In contrast, in 3-crypt and the other uranyl(V) complexes reported herein, there are several broad absorptions that lie in the visible region which may preclude effective population of any near-infrared excited states. Future work is directed at examining the luminescence properties of uranyl(V) complexes using higher powered laser excitation and at temperatures below that of liquid $\mathrm{N}_{2}$.

\section{CONCLUSION}

In conclusion, this study reports the first photoluminescence and Raman spectra of well-defined monomeric $\left[\mathrm{U}^{\mathrm{V}} \mathrm{O}_{2}\right]^{+}$ complexes. Experimental and theoretical studies support the assignment of the excited states in $\left[\mathrm{U}^{\mathrm{V}} \mathrm{O}_{2}\right]^{+}$as principally a quartet, whose origin is an admixture of amide to $\mathrm{U}(5 \mathrm{f})$ and $\mathrm{O}_{(\mathrm{yl})}$ to $\mathrm{U}(5 \mathrm{f})$ with a unique vibrational progression (with smaller contributions from intra $5 f$ excitations) where the emission band at $475 \mathrm{~nm}$ is best described computationally as an open-shell doublet or quartet with a high degree of mixing (compared to the well-defined triplet $5 \mathrm{f} \delta_{\mathrm{u}}$ excited state in uranyl(VI)). Overall, the clear definition of these luminescence steady-state and time-resolved features of the $\left[\mathrm{U}^{\mathrm{V}} \mathrm{O}_{2}\right]^{+}$moiety in monomeric and dimeric complexes ${ }^{20,30-32}$ should enable detailed studies of $\left[\mathrm{U}^{\mathrm{V}} \mathrm{O}_{2}\right]^{+}$in biological and engineered environments. $^{18-20,73,81,82}$

\section{ASSOCIATED CONTENT}

\section{Supporting Information}

The Supporting Information is available free of charge at https://pubs.acs.org/doi/10.1021/jacs.1c05184.

Detailed experimental procedures, spectroscopic analysis (NMR, UV-vis-NIR, IR, Raman), crystallographic studies, additional photoluminescence experiments, discussion, and computational details (PDF)

\section{Accession Codes}

CCDC 1944749-1944759 contain the supplementary crystallographic data for this paper. These data can be obtained free of charge via www.ccdc.cam.ac.uk/data_request/cif, or by emailing data_request@ccdc.cam.ac.uk, or by contacting The Cambridge Crystallographic Data Centre, 12 Union Road, Cambridge CB2 1EZ, UK; fax: +44 1223336033.

\section{AUTHOR INFORMATION}

\section{Corresponding Authors}

Henry S. La Pierre - Friedrich-Alexander-University Erlangen-Nürnberg (FAU), Department of Chemistry and Pharmacy, Inorganic Chemistry, 91058 Erlangen, Germany; School of Chemistry and Biochemistry and Nuclear and Radiological Engineering and Medical Physics Program, School of Mechanical Engineering, Georgia Institute of Technology, Atlanta, Georgia 30332-0400, United States; ○ orcid.org/0000-0002-0895-0655; Email: la_pierre@ chemistry.gatech.edu

Louise S. Natrajan - Centre for Radiochemistry Resesarch, Department of Chemistry, School of Natural Sciences and Photon Science Institute, The University of Manchester, Manchester M13 9PL, U.K.; (1) orcid.org/0000-0002-94513557; Email: louise.natrajan@manchester.ac.uk

\section{Authors}

Fabrizio Ortu - Centre for Radiochemistry Resesarch, Department of Chemistry, School of Natural Sciences, The University of Manchester, Manchester M13 9PL, U.K.; School of Chemistry, University of Leicester, Leicester LE1 7RH, U.K.; 1 orcid.org/0000-0002-1743-8338

Simon Randall - Centre for Radiochemistry Resesarch, Department of Chemistry, School of Natural Sciences, The University of Manchester, Manchester M13 9PL, U.K.

David J. Moulding - Centre for Radiochemistry Resesarch, Department of Chemistry, School of Natural Sciences, The University of Manchester, Manchester M13 9PL, U.K.

Adam W. Woodward - Centre for Radiochemistry Resesarch, Department of Chemistry, School of Natural Sciences and Photon Science Institute, The University of Manchester, Manchester M13 9PL, U.K.

Andrew Kerridge - Department of Chemistry, Lancaster University, Lancaster LA1 4YB, U.K.; 10 orcid.org/00000002-2876-1202

Karsten Meyer - Friedrich-Alexander-University ErlangenNürnberg (FAU), Department of Chemistry and Pharmacy, 
Inorganic Chemistry, 91058 Erlangen, Germany;

(1) orcid.org/0000-0002-7844-2998

Complete contact information is available at:

https://pubs.acs.org/10.1021/jacs.1c05184

\section{Author Contributions}

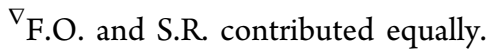

\section{Notes}

The authors declare no competing financial interest.

\section{ACKNOWLEDGMENTS}

This material is based upon work supported by the U.K. Engineering and Physical Sciences (EPSRC) as a Career Acceleration Fellowship (LN), studentship (SR) Grant EP/ G004846/1, an EPSRC delivering impact award (LN, SR), EPSRC Grant EP/K039547/1 (XRD and NMR services), the Leverhulme Trust for a Research Leadership Award (LN) and PDRA funding (FO), Grant RL-2012-072, and the Royal Society for a small equipment grant (LN). AK acknowledges the High End Computing Facility at Lancaster University for access to HPC resources, and HSL was supported at GT by the U.S. Department of Energy, Office of Science, Office of Basic Energy Sciences, Heavy Element Chemistry Program, under Award DE-SC0019385. KM acknowledges FAU and the Bundesministerium für Bildung und Forschung ( $f$-Char, $\mathrm{BMBF}$ support code 02NUK059E) for generous funding.

\section{REFERENCES}

(1) Zhang, Z.; Pitzer, R. M. Application of Relativistic Quantum Chemistry to the Electronic Energy Levels of the Uranyl Ion. J. Phys. Chem. A 1999, 103 (34), 6880-6886.

(2) Fortier, S.; Hayton, T. W. Oxo ligand functionalization in the uranyl ion $\left(\mathrm{UO}_{2}{ }^{2+}\right)$. Coord. Chem. Rev. 2010, 254 (3-4), 197-214.

(3) La Pierre, H. S.; Meyer, K. Uranium-ligand multiple bonding in uranyl analogues, $[\mathrm{L}=\mathrm{U}=\mathrm{L}]^{\mathrm{n}+}$, and the inverse trans influence. Inorg. Chem. 2013, 52 (2), 529-539.

(4) Hayton, T. W. Understanding the origins of $\mathrm{O}_{\mathrm{yl}}-\mathrm{U}-\mathrm{O}_{\mathrm{yl}}$ bending in the uranyl $\left(\mathrm{UO}_{2}{ }^{2+}\right)$ ion. Dalton Trans. 2018, 47, 1003-1009.

(5) Denning, R. G. Electronic Structure and Bonding in Actinyl Ions; Springer: Berlin, 1992; Vol. 79.

(6) Syt'ko, V. V.; Umreiko, D. S. Spectroscopic Properties and Electronic Structure of Uranyl Complex Compounds. J. Appl. Spectrosc. 1998, 65 (6), 857-870.

(7) Denning, R. G.; Snellgrove, T. R.; Woodwark, D. R. The electronic structure of the uranyl ion. Mol. Phys. 1979, 37 (4), 11091143.

(8) Denning, R. G. Electronic Structure and Bonding in Actinyl Ions and their Analogs. J. Phys. Chem. A 2007, 111 (20), 4125-4143.

(9) Arnold, P. L.; Love, J. B.; Patel, D. Pentavalent uranyl complexes. Coord. Chem. Rev. 2009, 253 (15-16), 1973-1978.

(10) Natrajan, L. S.; Swinburne, A. N.; Andrews, M. B.; Randall, S.; Heath, S. L. Redox and environmentally relevant aspects of actinide(IV) coordination chemistry. Coord. Chem. Rev. 2014, 266267, 171-193.

(11) Ekstrom, A. Kinetics and mechanism of the disproportionation of uranium(V). Inorg. Chem. 1974, 13 (9), 2237-2241.

(12) Steele, H.; Taylor, R. J. A Theoretical Study of the Inner-Sphere Disproportionation Reaction Mechenism of the Pentavalent Actinyl Ions. Inorg. Chem. 2007, 46 (16), 6311-6318.

(13) Jones, D. L.; Andrews, M. B.; Swinburne, A. N.; Botchway, S. W.; Ward, A. D.; Lloyd, J. R.; Natrajan, L. S. Fluorescence spectroscopy and microscopy as tools for monitoring redox transformations of uranium in biological systems. Chem. Sci. 2015, 6, 5133-5138.
(14) Selbin, J.; Ortego, J. D. Chemistry of uranium(V). Chem. Rev. 1969, 69 (5), 657-671.

(15) Docrat, T. I.; Mosselmans, J. F. W.; Chrnock, J. M.; Whiteley, M. W.; Collison, D.; Livens, F. R.; Jones, C.; Edmiston, M. J. X-ray Absorption Spectroscopy of Tricarbonatodioxouranate(V), $\left[\mathrm{UO}_{2}\left(\mathrm{CO}_{3}\right)_{3}\right]^{5-}$, in Aqueous Solution. Inorg. Chem. 1999, 38 (9), $1879-1882$.

(16) Liddle, S. T. The Renaissance of Non-Aqueous Uranium Chemistry. Angew. Chem., Int. Ed. 2015, 54 (30), 8604-8641.

(17) Graves, C. R.; Kiplinger, J. L. Pentavalent uranium chemistry: synthetic pursuit of a rare oxidation state. Chem. Commun. 2009, No. 26, 3831-53.

(18) Faizova, R.; Scopelliti, R.; Chauvin, A.-S.; Mazzanti, M. Synthesis and Characterization of a Water Stable Uranyl(V) Complex. J. Am. Chem. Soc. 2018, 140 (42), 13554-13557.

(19) Agarwal, R.; Dumpala, R. M. R.; Sharma, M. K.; Yadav, A. K.; Ghosh, T. K. Stabilization of Uranyl(V) by Dipicolinic Acid in Aqueous Medium. Dalton Trans. 2021, 50, 1486.

(20) Faizova, R.; Fadaei-Tirani, F.; Chauvin, A.-S.; Mazzanti, M. Synthesis and Characterization of Water Stable Uranyl(V) Complexes. Angew. Chem., Int. Ed. 2021, 60, 8227.

(21) Berthet, J. C.; Nierlich, M.; Ephritikhine, M. Isolation of a uranyl $\left[\mathrm{UO}_{2}\right]^{+}$species: crystallographic comparison of the dioxouranium(V) and (VI) compounds $\left[\mathrm{UO}_{2}\left(\mathrm{OPPh}_{3}\right)_{4}\right](\mathrm{OTf})_{\mathrm{n}}(\mathrm{n}$ = 1, 2). Angew. Chem., Int. Ed. 2003, 42 (17), 1952-4.

(22) Berthet, J. C.; Siffredi, G.; Thuery, P.; Ephritikhine, M. Easy access to stable pentavalent uranyl complexes. Chem. Commun. 2006, No. 30, 3184-6.

(23) Natrajan, L. S.; Burdet, F.; Pecaut, J.; Mazzanti, M. Synthesis and Structure of a Stable Pentavalent-Uranyl Coordination Polymer. J. Am. Chem. Soc. 2006, 128 (122), 7152-7153.

(24) Arnold, P. L.; Patel, D.; Wilson, C.; Love, J. B. Reduction and selective oxo group silylation of the uranyl dication. Nature 2008, 451 (7176), 315-7.

(25) Nocton, G.; Horeglad, P.; Pecaut, J.; Mazzanti, M. Polynuclear Cation-Cation Complexes of Pentavalent Uranyl: Relating Stability and Magnetic Properties to Structure. J. Am. Chem. Soc. 2008, 130 (49), 16633-16645.

(26) Arnold, P. L.; Jones, G. M.; Odoh, S. O.; Schreckenbach, G.; Magnani, N.; Love, J. B. Strongly coupled binuclear uranium-oxo complexes from uranyl oxo rearrangement and reductive silylation. Nat. Chem. 2012, 4 (3), 221-227.

(27) Chatelain, L.; Mougel, V.; Pécaut, J.; Mazzanti, M. Magnetic communication and reactivity of a stable homometallic cation-cation trimer of pentavalent uranyl. Chem. Sci. 2012, 3, 1075-1079.

(28) Mills, D. P.; Cooper, O. J.; Tuna, F.; McInnes, E. J.; Davies, E. S.; McMaster, J.; Moro, F.; Lewis, W.; Blake, A. J.; Liddle, S. T. Synthesis of a uranium(VI)-carbene: reductive formation of uranyl(V)-methanides, oxidative preparation of a $\left[\mathrm{R}_{2} \mathrm{C}=\mathrm{U}=\mathrm{O}\right]^{2+}$ analogue of the $[\mathrm{O}=\mathrm{U}=\mathrm{O}]^{2+}$ uranyl ion $\left(\mathrm{R}=\mathrm{Ph}_{2} \mathrm{PNSiMe}_{3}\right)$, and comparison of the nature of $\mathrm{U}^{\mathrm{IV}}=\mathrm{C}, \mathrm{U}^{\mathrm{V}}=\mathrm{C}$, and $\mathrm{U}^{\mathrm{VI}}=\mathrm{C}$ double bonds. J. Am. Chem. Soc. 2012, 134 (24), 10047-10054.

(29) Mougel, V.; Chatelain, L.; Pecaut, J.; Caciuffo, R.; Colineau, E.; Griveau, J. C.; Mazzanti, M. Uranium and manganese assembled in a wheel-shaped nanoscale single-molecule magnet with high spinreversal barrier. Nat. Chem. 2012, 4, 1011-1017.

(30) Mizuoka, K.; Tsushima, S.; Hasegawa, M.; Hoshi, T.; Ikeda, Y. Electronic Spectra of Pure Uranyl(V) Complexes: Characteristic Absorption Bands Due to a $\mathrm{U}^{\mathrm{V}} \mathrm{O}^{2+}$ Core in Visible and Near-Infrared Regions. Inorg. Chem. 2005, 44 (18), 6211-6218.

(31) Grossmann, K.; Arnold, T.; Ikeda-Ohno, A.; Steudtner, R.; Geipel, G.; Bernhard, G. Fluorescence properties of a uranyl(V)carbonate species $\left[\mathrm{U}(\mathrm{V}) \mathrm{O}_{2}\left(\mathrm{CO}_{3}\right)_{3}\right]^{5-}$ at low temperature. Spectrochim. Acta, Part A 2009, 72 (2), 449-53.

(32) Steudtner, R.; Arnold, T.; Großmann, K.; Geipel, G.; Brendler, V. Luminescence spectrum of uranyl(V) in 2-propanol perchlorate solution. Inorg. Chem. Commun. 2006, 9 (9), 939-941. 
(33) Natrajan, L. S. Developments in the photophysics and photochemistry of actinide ions and their coordination compounds. Coord. Chem. Rev. 2012, 256 (15-16), 1583-1603.

(34) Cobb, P. J.; Moulding, D. J.; Ortu, F.; Randall, S.; Wooles, A. J.; Natrajan, L. S.; Liddle, S. T. Uranyl-tri- bis(silyl)amide Alkali Metal Contact and Separated Ion Pair Complexes. Inorg. Chem. 2018, 57 (11), 6571-6583.

(35) Andersen, R. A. Tris((hexamethyldisilyl)amido)uranium(III): preparation and coordination chemistry. Inorg. Chem. 1979, 18 (6), $1507-1509$.

(36) Tilley, T. D.; Andersen, R. A.; Zalkin, A. Tertiary phosphine complexes of the f-block metals. Crystal structure of $\mathrm{Yb}[\mathrm{N}$ $\left.\left(\mathrm{SiMe}_{3}\right)_{2}\right]_{2}\left[\mathrm{Me}_{2} \mathrm{PCH}_{2} \mathrm{CH}_{2} \mathrm{PMe}_{2}\right]$ : evidence for a ytterbium- $\gamma$-carbon interaction. J. Am. Chem. Soc. 1982, 104 (13), 3725-3727.

(37) Evans, W. J.; Drummond, D. K.; Zhang, H.; Atwood, J. L. Synthesis and $\mathrm{x}$-ray crystal structure of the divalent [bis(trimethylsilyl)amido] samarium complexes $\left[\left(\mathrm{Me}_{3} \mathrm{Si}\right)_{2} \mathrm{~N}\right]_{2} \mathrm{Sm}(\mathrm{THF})_{2}$ and $\left\{\left[\left(\mathrm{Me}_{3} \mathrm{Si}\right)_{2} \mathrm{~N}\right] \mathrm{Sm}(\mu-\mathrm{I})(\mathrm{DME})(\mathrm{THF})\right\}_{2}$. Inorg. Chem. 1988, 27 (3), 575-579.

(38) Zalkin, A.; Brennan, J. G.; Andersen, R. A. Tris[bis(trimethylsilyl)amido](trimethylsilylimido)uranium(V). Acta Crystallogr., Sect. C: Cryst. Struct. Commun. 1988, C44, 1553-1554.

(39) Crozier, A. R.; Bienfait, A. M.; Maichle-Mossmer, C.; Tornroos, K. W.; Anwander, R. A homoleptic tetravalent cerium silylamide. Chem. Commun. 2013, 49, 87-89.

(40) Mullane, K. C.; Lewis, A. J.; Yin, H.; Carroll, P. J.; Schelter, E. J. Anomalous one-electron processes in the chemistry of uranium nitrogen multiple bonds. Inorg. Chem. 2014, 53 (17), 9129-9139.

(41) Goodwin, C. A.; Chilton, N. F.; Vettese, G. F.; Moreno Pineda, E.; Crowe, I. F.; Ziller, J. W.; Winpenny, R. E.; Evans, W. J.; Mills, D. P. Physicochemical Properties of Near-Linear Lanthanide(II) Bis(silylamide) Complexes $(\mathrm{Ln}=\mathrm{Sm}, \mathrm{Eu}, \mathrm{Tm}, \mathrm{Yb})$. Inorg. Chem. 2016, 55 (20), 10057-10067.

(42) Ryan, A. J.; Angadol, M. A.; Ziller, J. W.; Evans, W. J. Isolation of $\mathrm{U}(\mathrm{II})$ compounds using strong donor ligands, $\mathrm{C}_{5} \mathrm{Me}_{4} \mathrm{H}$ and $\mathrm{N}\left(\mathrm{SiMe}_{3}\right)_{2}$, including a three-coordinate $\mathrm{U}(\mathrm{II})$ complex. Chem. Commun. 2019, 55, 2325-2327.

(43) Brennan, J. G. Ph.D. Thesis. University of California, Berkeley, 1985.

(44) Stewart, J. L. Ph.D. Thesis. University of California, Berkeley, 1988.

(45) Burns, C. J.; Smith, W. H.; Huffman, J. C.; Sattelberger, A. P. Uranium(VI) organoimido complexes. J. Am. Chem. Soc. 1990, 112 (8), 3237-3239.

(46) Lewis, A. J.; Nakamaru-Ogiso, E.; Kikkawa, J. M.; Carroll, P. J.; Schelter, E. J. Pentavalent uranium trans-dihalides and -pseudohalides. Chem. Commun. 2012, 48, 4977-4979.

(47) Woodall, S. D.; Swinburne, A. N.; lal Banik, N.; Kerridge, A.; Di Pietro, P.; Adam, C.; Kaden, P.; Natrajan, L. S. Neptunyl(VI) centred visible LMCT emission directly observable in the presence of uranyl(VI). Chem. Commun. 2015, 51, 5402-5405.

(48) Hayton, T. W.; Wu, G. Mixed-Ligand Uranyl(V) $\beta$ Diketiminate $/ \beta$-Diketonate Complexes: Synthesis and Characterization. Inorg. Chem. 2008, 47 (16), 7415-7423.

(49) Mougel, V.; Horeglad, P.; Nocton, G.; Pecaut, J.; Mazzanti, M. Cation-Cation Complexes of Pentavalent Uranyl: From Disproportionation Intermediates to Stable Clusters. Chem. - Eur. J. 2010, 16, 14365-14377.

(50) Nocton, G.; Horeglad, P.; Vetere, V.; Pecaut, J.; Dubois, L.; Maldivi, P.; Edelstein, N. M.; Mazzanti, M. Synthesis, Structure, and Bonding of Stable Complexes of Pentavalent Uranyl. J. Am. Chem. Soc. 2010, 132 (2), 495-508.

(51) Hayton, T. W.; Wu, G. Synthesis, Characterization, and Reactivity of a Uranyl $\beta$-Diketiminate Complex. J. Am. Chem. Soc. 2008, 130 (6), 2005-2014.

(52) Spencer, L. P.; Schelter, E. J.; Yang, P.; Gdula, R. L.; Scott, B. L.; Thompson, J. D.; Kilplinger, J. L.; Batista, E. R.; Boncella, J. M. Cation-Cation Interactions, Magnetic Communication, and Reactivity of the Pentavalent Uranium Ion $\left[\mathrm{U}(\mathrm{N} t \mathrm{Bu})_{2}\right]^{+}$. Angew. Chem. 2009, $121,3853-3856$

(53) Jilek, R. E.; Spencer, L. P.; Lewis, R. A.; Scott, B. L.; Hayton, T. W.; Boncella, J. M. A Direct Route to Bis(imido)uranium(V) Halides via Metathesis of Uranium Tetrachloride. J. Am. Chem. Soc. 2012, 134 (24), 9876-9878.

(54) Cladis, D. P.; Kiernicki, J. J.; Fanwick, P. E.; Bart, S. C. Multielectron reduction facilitated by a trianionic pyridine(diimine) ligand. Chem. Commun. 2013, 49, 4169-4171.

(55) Evans, D. F. The determination of the paramagnetic susceptibility of substances in solution by nuclear magnetic resonance. J. Chem. Soc. 1959, 2003-2005.

(56) Kindra, D. R.; Evans, W. J. Magnetic Susceptibility of Uranium Complexes. Chem. Rev. 2014, 114, 8865-8882.

(57) Boudreaux, E. A.; Mulay, L. N. Theory and Applications of Molecular Paramagnetism; Wiley: New York, 1976.

(58) Shannon, R. D. Revised effective ionic radii and systematic studies of interatomic distances in halides and chalcogenides. Acta Crystallogr., Sect. A: Cryst. Phys., Diffr., Theor. Gen. Crystallogr. 1976, A32, 751-767.

(59) Zegke, M.; Nichol, G. S.; Arnold, P. L.; Love, J. B. Catalytic one-electron reduction of uranyl(VI) to Group 1 uranyl(V) complexes via $\mathrm{Al}(\mathrm{III})$ coordination. Chem. Commun. 2015, 51, $5876-5879$.

(60) Selbin, J.; Ortego, J. D.; Gritzner, G. Electronic spectral studies of some uranium(V) compounds. Inorg. Chem. 1968, 7 (5), 976-982.

(61) Cohen, D. The preparation and spectrum of uranium $(\mathrm{V})$ ions in aqueous solutions. J. Inorg. Nucl. Chem. 1970, 32, 3525-3530.

(62) Nagai, T.; Fujii, T.; Shirai, O.; Yamana, H. Study on Redox Equilibrium of $\mathrm{UO}_{2}{ }^{2+} / \mathrm{UO}_{2}{ }^{+}$in Molten $\mathrm{NaCl}-2 \mathrm{CsCl}$ by UV-Vis Spectrophotometry. J. Nucl. Sci. Technol. 2004, 41 (6), 690-695.

(63) Merritt, J. M.; Han, J.; Heaven, M. C. Spectroscopy of the $\mathrm{UO}_{2}{ }^{+}$cation and the delayed ionization of $\mathrm{UO}_{2}$. J. Chem. Phys. 2008, $128(8), 084304$.

(64) Ruiperez, F.; Danilo, C.; Real, F.; Flament, J.-P.; Vallet, V.; Wahlgren, U. An ab inito Theoretical Study of the Electornic Structure of $\mathrm{UO}^{2+}$ and $\left[\mathrm{UO}_{2}\left(\mathrm{CO}_{3}\right)_{3}\right]^{5-}$. J. Phys. Chem. A 2009, 113 (8), $1420-1428$.

(65) Su, J.; Schwarz, W. H.; Li, J. Electronic spectra and excited states of neptunyl and its $\left[\mathrm{NpO}_{2} \mathrm{Cl}_{4}\right]^{2-}$ complex. Inorg. Chem. 2012, 51 (5), 3231-3238.

(66) Termes, S. C.; Pope, M. T. Stabilization of Uranium(IV) in Heteropoly Anions. Transition Met. Chem. 1978, 3, 103-108.

(67) Li, X.-L.; Luo, J.; Lin, T.-W.; Liao, L.-F.; Nie, C.-M. Density functional theory investigation of nonsymmetrically substituted uranyl-salophen complexes. J. Radioanal. Nucl. Chem. 2016, 307, 407-417.

(68) Infante, I.; Eliav, E.; Vilkas, M. J.; Ishikawa, Y.; Kaldor, U.; Visscher, L. A Fock space coupled cluster study on the electronic structure of the $\mathrm{UO}_{2}, \mathrm{UO}_{2}{ }^{+}, \mathrm{U}^{4+}$, and $\mathrm{U}^{5+}$ species. J. Chem. Phys. 2007, 127 (12), 124308.

(69) Matsika, S.; Pitzer, R. M.; Reed, D. T. Intensities in the Spectra of Actinyl Ions. J. Phys. Chem. A 2000, 104 (51), 11983-11992.

(70) Bullock, J. I. Raman and Infrared Spectroscopic Studies of the Uranyl Ion: the Symmetric Stretching Frequency, Force Constants, and Bond Lengths. J. Chem. Soc. A 1969, 781-784.

(71) Schnaars, D. D.; Wilson, R. E. Structural and vibrational properties of $\mathrm{U}(\mathrm{VI}) \mathrm{O}_{2} \mathrm{Cl}_{4}{ }^{2-}$ and $\mathrm{Pu}(\mathrm{VI}) \mathrm{O}_{2} \mathrm{Cl}_{4}{ }^{2-}$ complexes. Inorg. Chem. 2013, 52 (24), 14138-14147.

(72) Talbot-Eeckelaers, C.; Pope, S. J. A.; Hynes, A. J.; Copping, R.; Jones, C. J.; Taylor, R. J.; Faulkner, S.; Sykes, D.; Livens, F. R.; May, I. Luminescence from Neptunyl(VI) Species in Solution. J. Am. Chem. Soc. 2007, 129 (9), 2442-2443.

(73) Vettese, G. F.; Morris, K.; Natrajan, L. S.; Shaw, S.; Vitova, T.; Galanzew, J.; Jones, D. L.; Lloyd, J. R. Multiple Lines of Evidence Identify $\mathrm{U}(\mathrm{V})$ as a Key Intermediate during $\mathrm{U}(\mathrm{VI})$ Reduction by Shewanella oneidensis MR1. Environ. Sci. Technol. 2020, 54 (4), 22682276. 
(74) Perdew, J. P.; Burke, K.; Ernzerhof, M. Generalized Gradient Approximation Made Simple. Phys. Rev. Lett. 1996, 77 (18), 38653868.

(75) Adamo, C.; Barone, V. Toward Reliable Density Functional Methods without Adjustable Parameters: The PBE0Model. J. Chem. Phys. 1999, 110 (13), 6158-6170.

(76) Schafer, A.; Huber, C.; Ahlrichs, R. Fully Optimized Contracted Gaussian Basis Sets of Triple Zeta Valence Quality for Atoms Li to Kr. J. Chem. Phys. 1994, 100 (8), 5829-5835.

(77) Eichkorn, K.; Weigend, F.; Treutler, O.; Ahlrichs, R. Auxiliary Basis Sets for Main Row Atoms and Transition Metals and Their Use to Approximate Coulomb Potentials. Theor. Chem. Acc. 1997, 97 (14), 119-124.

(78) Küchle, W.; Dolg, M.; Stoll, H.; Preuss, H. Energy-Adjusted Pseudopotentials for the Actinides. Parameter Sets and Test Calculations for Thorium and Thorium Monoxide. J. Chem. Phys. 1994, 100 (10), 7535-7542.

(79) Cao, X.; Dolg, M. Segmented Contraction Scheme for SmallCore Actinide Pseudopotential Basis Sets. J. Mol. Struct.: THEOCHEM 2004, 673 (1-3), 203-209.

(80) Pierloot, K.; van Besien, E. Electronic structure and spectrum of $\mathrm{UO}_{2}{ }^{2+}$ and $\mathrm{UO}_{2} \mathrm{Cl}_{4}^{2-}$. J. Chem. Phys. 2005, 123 (20), 204309.

(81) McBriarty, M. E.; Kerisit, S.; Bylaska, E. J.; Shaw, S.; Morris, K.; Ilton, E. S. Iron Vacancies Accommodate Uranyl Incorporation into Hematite. Environ. Sci. Technol. 2018, 52 (11), 6282-6290.

(82) Roberts, H. E.; Morris, K.; Law, G. T. W.; Mosselmans, J. F. W.; Bots, P.; Kvashnina, K.; Shaw, S. Uranium(V) Incorporation Mechanisms and Stability in $\mathrm{Fe}(\mathrm{II}) / \mathrm{Fe}$ (III) (oxyhydr)Oxides. Environ. Sci. Technol. Lett. 2017, 4 (10), 421-426. 